\title{
CRIMINALS AND THE PRICE SYSTEM: EVIDENCE FROM CZECH METAL THIEVES
}

\section{Tomáš Brabenec Josef Montag}

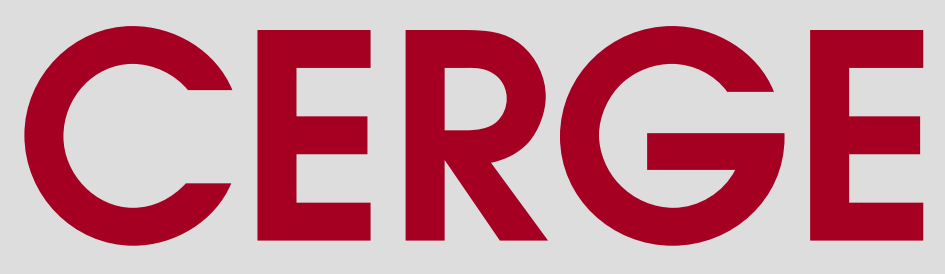




\title{
Working Paper Series $\quad 558$ (ISSN 1211-3298)
}

\section{Criminals and the Price System: Evidence from Czech Metal Thieves}

\author{
Tomáš Brabenec \\ Josef Montag
}

CERGE-EI

Prague, February 2016 
ISBN 978-80-7343-365-9 (Univerzita Karlova v Praze, Centrum pro ekonomický výzkum a doktorské studium)

ISBN 978-80-7344-369-6 (Národohospodářský ústav AV ČR, v. v. i.) 


\title{
Criminals and the Price System: Evidence from
}

\author{
Czech Metal Thieves*
}

\author{
Tomáš Brabenec ${ }^{\dagger}$ and Josef Montag
}

February 2016

\begin{abstract}
People steal copper and other nonferrous metals to sell them to scrap yard. Simultaneously, prices at scrap yards are set by the world market. We argue that shocks in metal prices represent a quasi-experimental variation in gains from crime. This allows us to estimate the behavioral parameters of supply of offenses and test the economic theory of criminal behavior. Our estimates suggest that the long-term elasticity of supply of metal thefts with respect to the re-sale value of stolen metal is between unity and 1.5. Moreover, the system tends to equilibriate quickly_-between 30 and 60 percent of a disequilibrium is corrected the following month and the monthly price elasticity estimates are around unity.
\end{abstract}

Key words: economics of crime, gains from crime, metal theft, rational model. JEL classification: K42, Q31, Q32.

\footnotetext{
*We wish to thank the following for their helpful comments: Richard Boylan, Jan Broulík, Pavel Č́žzek, Brendan Dooley, Jitka Dušková, Oren Gazal-Ayal, Martin Guzi, Petr Koráb, Peter Huber, Guido Maretto, David de Meza, Marie Obidzinski, Daniel Pi, and participants at the 2015 conference of the Society for Institutional and Organizational Economics at Harvard University, the 2015 conference of the European Association of Law and Economics at the University of Vienna, the 2015 Law and Economics Workshop at Erasmus University Rotterdam, the 2014 Young Economists' Meeting at Masaryk University in Brno, and the 2014 Annual Meeting of the German Law and Economics Association at Ghent University. We are grateful to Arnošt Danihel, Vladimír Stolín, and Bohuslav Zúbek from the Police Presidium of the Czech Republic for providing us with crime-level data on metal thefts. Parts of this paper were written between April and July 2014 while Josef Montag was a visiting researcher at the Tilburg Law and Economics Centre at Tilburg University; he gratefully acknowledges the centre's hospitality, support, and valuable discussions with TILEC's faculty and researchers. We also thank Annie Barton for careful editing. All remaining errors are our own responsibility.

†niversity of Economics, Prague. Email: brabenec.tom @ gmail.com.

¥Corresponding author: Velký Beranov 157, 58821, Czech Republic. Phone: +420 604715 714. Email: josef.montag@gmail.com.
} 


\section{Introduction}

Does opportunity make a thief? This paper exploits a quasi-natural experiment in the value of stolen goods in order to test predictions based on the economic theory of crime (Becker 1968; Ehrlich 1973; Posner 1985). ${ }^{1}$ This theory views a criminal act as a rational decision: a crime is attempted whenever the expected benefits exceed the costs. The model's main prediction is that a change in punishment or the probability of apprehension should, if everything else remains the same, result in a change in criminal activity. This is because the cost-benefit ratio reverses for the crimes at the margin.

Testing this model has proved notoriously difficult due to the lack of experimental variation in punishment severity or enforcement intensity. The problem is that policy shocks are likely to reflect shocks in criminal activity. Indeed, Tsebelis's (1989) model, which treats enforcement as fully endogenous, predicts no equilibrium relationship between the severity of punishment and crime rates - this is because any improvement in the latter results in relaxed enforcement and a subsequent rebound of criminal activity. This may seem to be an extreme prediction. Consider, however, that Montag (2014) investigated the effects of a substantial increase in sanctions for traffic law offenses in the Czech Republic, and found that the immediate effect of such a change was a one third decline in road-traffic-accident-related fatalities. However, a quick rebound followed within the ensuing months and there was no identifiable effect beyond one year after the reform. At the same time, traffic police enforcement activity (though not manpower) declined.

Finding an exogenous source of variation in determinants of the value of criminal activity is thus crucial for empirical research into criminal behavior. To overcome the simultaneity problem, Levitt $(1997,2002)$ uses political cycles and firefighters, respectively, as instruments for police enforcement. Di Tella and Schargrodsky (2004) exploit shocks in the geographic allocation of the police force following a terrorist attack in Buenos Aires and, in a similar vein, Klick and Tabarrok (2005) use shocks to police presence in

${ }^{1}$ The origins of the approach can, however, be traced back to Beccaria (1995 [1764]) and Bentham (1823, 2008 [1830]). For an overview article see Ehrlich (1996). 
Washington, D.C. following changes in the terror alert levels. All four papers find that increases in police enforcement deter crime.

In this paper, we test the economic theory of criminal behavior using exogenous variation in the monetary gains from crime that accrue to the thieves. This way, we complement the existing body of literature, which studies shocks in deterrence. Previous literature testing the relationship between gains from crime and criminal behavior was plagued by the difficulty of accurately measuring gains from crime and yielded contradictory results (Chisholm and Choe 2005). In this paper we make use of a clear-cut measure of gains from crime- the market value of the stolen goods. This approach also has the distinct advantage that it directly tests the economic nature of decisions about criminal activity, since changes in the cost-benefit structure of criminal opportunities induced by shocks in the market value of stolen goods are purely monetary in nature.

Specifically, we examine how metal thieves in the Czech Republic respond to changes in the prices of nonferrous metals. After all, the metal is of no value to the thieves, except in as far as it can be sold to a scrap yard. Thus the benefits from a metal theft depend directly on the price of the given metal. At the same time, nonferrous metals are commodities and their prices are determined on the world market, with the majority of futures transactions concentrated at the London Metal Exchange (LME). ${ }^{2}$ We show that this price information is then directly transferred to scrap markets. ${ }^{3}$ We argue that this

\footnotetext{
2The London Metal Exchange is the world's largest market in options and futures contracts on base and other metals; more than 80 percent of all nonferrous metal futures business is transacted on LME platforms (see "A Guide to the LME," London Metal Exchange, PDF file, 2014, at http://www.lme.com/ /media/Files/Brochures/A Guide to the LME.pdf, last accessed October 3, 2014).

${ }^{3}$ See also Aruga and Managi (2011), Draca, Koutmeridis, and Machin (2015), Labys, Rees, and Elliott (1971), and Watkins and McAleer (2004). One of our colleagues has argued that scrapyards may know the 'usual suspects' and take a cut of their gains. This may also happen when someone is selling objects that scrapyards are barred from buying (such as manhole covers, traffic signs, or headstones). As a result, sale prices for the thieves would then be lower than the standard scrapyard prices. We believe, however, that this would be a problem if the size of the cut was a function of prices (or the supply of thefts). Suppose that this is the case and scrap yards are able to take a bigger cut when the supply of stolen copper goes up. Then, we could still estimate the effect of prices on thefts, which is weakened by this ability of scrap yards to cut into the price. In reality, this would require that scrapyards exert some market power. However, during the period covered by our data (2003-2012), scrap yards were essentially free-entry businesses without any government regulation (a directive of the Ministry of the Environment prohibiting cash payments for scrap metal was instituted only recently, in March 2015). Competition should limit scrap yard's ability to take cuts in prices beyond what would be cost-justified (from the yards' point of view). In summary, this phenomenon would most likely work against our hypothesis, yielding a conservative bias in our results.

An analogous argument applies to the concern that we equate prices with gains from theft, which ignores the cost of stealing and transporting the goods. This again would only be a problem if the costs were a
} 


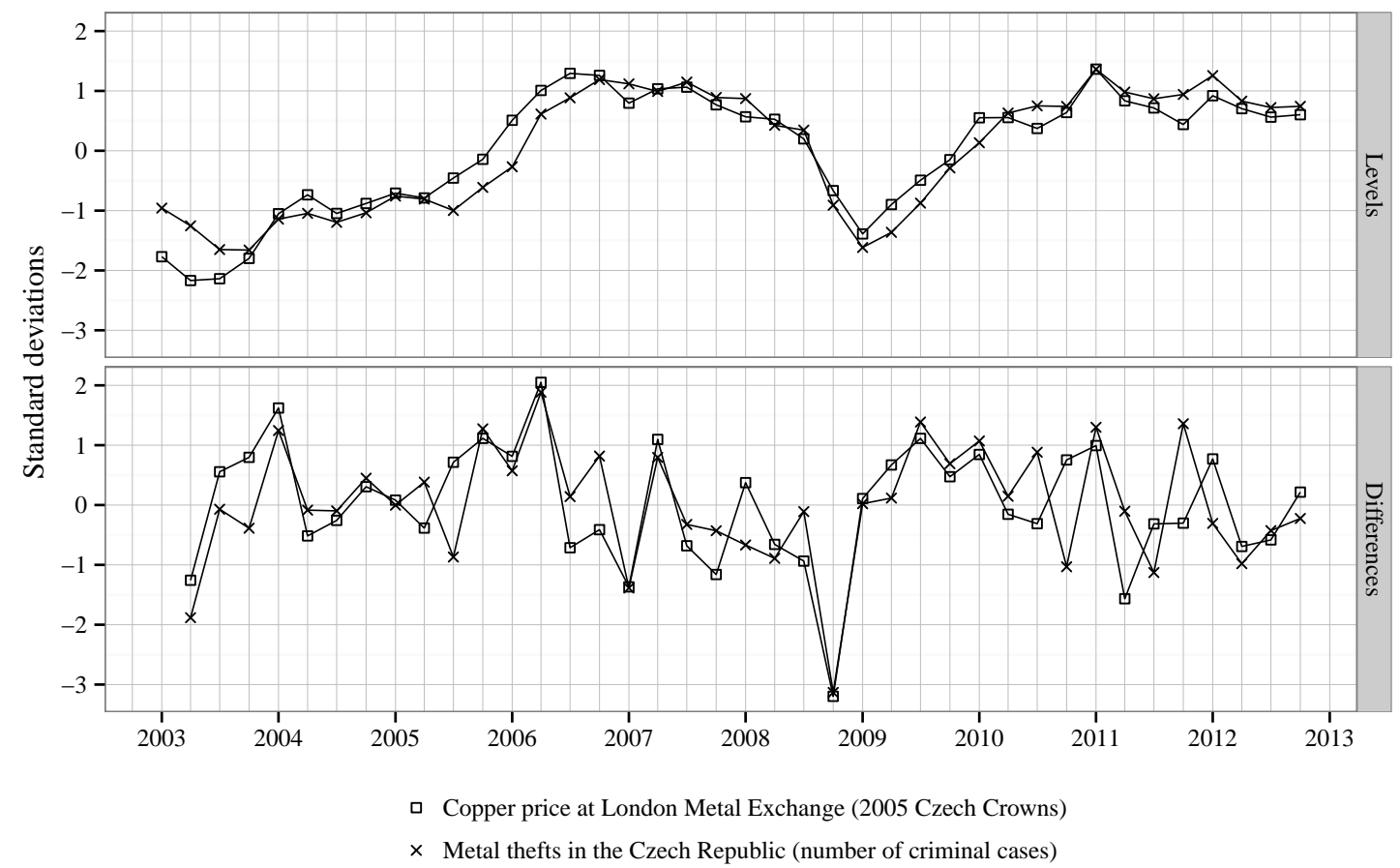

Figure 1: Copper prices and the number of criminal cases involving nonferrous metals reported to the Czech Police (quarterly averages, thefts are lagged by one month). Data are deseasoned, demeaned, and divided by respective standard deviations.

setup represents a quasi-natural experiment, enabling us to test the causal links postulated by the economic model of criminal behavior and estimate the elasticity of the "supply of offenses' (Becker 1968) with respect to gains from crime. The relationship between thefts and prices in our data is shown in Figure 1, which plots levels and first differences of normalized and deseasoned quarterly series of copper prices at the London Metal Exchange and metal thefts in the Czech Republic.

Interestingly, the relationship between thefts and the market value of stolen goods has received rather limited research attention. Sidebottom, Belur, Bowers, Tompson, and Johnson (2011) and Sidebottom, Ashby, and Johnson (2014) have recently studied the relationship between copper prices and the number of police recorded copper cable thefts from the British railway network and found the elasticities of thefts with respect to copper price to be around three and unity, respectively. Similarly, Posick, Rocque, Whiteacre, and Mazeika (2012) reported a positive a correlation between metal prices and the number function of criminal activity, which is entirely possible. If marginal costs increase in the number of thefts, our changes in prices will overstate the changes in gains from crime, making the results in this paper conservative. 
of instances of metal from commercial and residential dwellings in Rochester, NY. Most recently, Draca, Koutmeridis, and Machin (2015) investigated the relationship between prices and thefts in a panel of stolen property types in London Metropolitan Police data. They too found a systematically positive relationship between prices and thefts. ${ }^{4}$

This paper complements and extends these recent studies. It differs in three main respects: (i) We possess a very detailed crime-level dataset of all nonferrous metal-related thefts that occurred in the Czech Republic during the ten-year period from 2003 until 2012. (ii) We offer a more involved analytical approach. Economic theory predicts an equilibrium relationship exists between gains from crime and criminal activity, or the supply of offenses. That relationship requires the existence of a short-term equilibriating mechanism that corrects deviations from the equilibrium. In econometric terms, the analysis needs to proceed in the co-integration framework (Engle and Granger 1987; Murray 1994). (iii) Last but not least, our detailed data enable us to perform extensive sensitivity analyses and a number of robustness checks in order to address sample selection concerns and alternative explanations of our findings.

Understanding the behavioral background behind metal thefts is important because this criminal activity represents a serious economic and security issue. Although many metal thefts may result in little or no damage, others are highly damaging. The average value of stolen material per theft in our data is $33,000 \mathrm{CZK}(\$ 1,300)$ and the average damage is about $40,000 \mathrm{CZK}(\$ 1,600)$, approximately double the average monthly net wage in the Czech Republic. Notwithstanding these non-negligible costs, metal theft often results in damage to public infrastructure. Three bridges were recently stolen in the Czech Republic, Turkey, and the United States. ${ }^{5}$ Sidebottom, Ashby, and Johnson (2014) document the large number of live copper cable thefts from the British railway

\footnotetext{
${ }^{4}$ See also d'Este (2014) who looks at the effects of pawnshop availability on property crime in the US. He finds an elasticity of property thefts to pawnshops of between 0.8 and 1.5.

${ }^{5}$ See “Thieves Steal Local Bridge," CBS Pittsburgh, Online, October 7, 2011, at http://pittsburgh.cbslocal. com/2011/10/07/thieves-steal-bridge-in-lawrence-county (last accessed on October 5, 2014); "Czech metal thieves dismantle 10-ton bridge," The Telegraph, Online, April 30, 2012, at http://www.telegraph.co.uk/news/ newstopics/howaboutthat/9235705/Czech-metal-thieves-dismantle-10-ton-bridge.html (last accessed on October 5, 2014); and “Thieves Steal Entire Bridge in Western Turkey," Time, Online, March 21, 2013, at http://newsfeed.time.com/2013/03/21/thieves-steal-entire-bridge-in-western-turkey (last accessed on October $5,2014)$.
} 
network; these live cables distribute electricity to trains but also to line-side signals. These crimes not only threaten safety, but also cause substantial delays and costs related to the replacement of stolen material and repairs to damaged equipment; these costs are often disproportionate to the value of the stolen metal. This can be illustrated by three examples from the United States: tornado warning sirens were rendered inoperable because they were stripped of copper wiring; copper wires stolen from a transformer resulted in a power outage (damage $\$ 500,000$ ); lastly, loss of crops occurred due to wires being stolen from irrigation wells (total loss of $\$ 10$ million). ${ }^{6}$ Perhaps it is no coincidence that these three events all happened in 2007 and early 2008, while copper prices were at historically high levels. ${ }^{7}$

Our results can be summarized as follows. Finding that prices and thefts are, indeed, cointegrated, we are able to estimate the parameters of the long-term equilibrium relationship between gains from crime and the supply of offenses. We then recover the parameters of the error-correction mechanism, which animates the real-time adjustments to shocks and determines the rate at which disequilibria are corrected. We find the long-term elasticity of metal thefts with respect to the re-sale value of stolen metal to be between unity and 1.5. The short-term (monthly) elasticity is estimated around unity. In addition, the system tends to equilibriate quickly—between 30 and 60 percent of a shock is predicted to be corrected the following month. These results are robust to alternative specifications, controlling for general crime trends, enforcement intensity, business cycles, weather, and political cycles. Importantly, we show that our results are not an artifact of a purely mechanical correlation between the volume of recorded crimes and the prices of stolen goods.

\footnotetext{
${ }^{6}$ See “Copper Thefts Threaten U.S. Critical Infrastructure," Federal Bureau of Investigation, Criminal Intelligence Section, Online, September 15, 2008, at http:/www.fbi.gov/stats-services/publications/copperthefts (last accessed on October 5, 2014) and resources therein. For policy papers on costs of metal thefts, further background, and potential measures see Bennett (2008, 2012a,b); Kooi (2010); and Lipscombe and Bennett (2012).

${ }^{7}$ Also, the three bridges mentioned, were stolen between 2011 and 2013, after steel prices returned to their pre-recession levels.
} 


\section{Data}

The crime data analyzed in this paper were drawn from the Statistical Register of Criminality ${ }^{8}$ managed by the Police Presidium of the Czech Republic, which records all criminal offenses handled by the police. We received data from this register relating to all criminal cases in which one of the objects of the crime was a nonferrous metal, in total 44,613 records from the period 2003-2012. The raw data set contains information on the criminal classification of each offense, its location, the date the police learned about the case, the primary and secondary objects of the crime, and whether, how, and when the case ended. We focus on primary metal thefts, that is thefts in which metals were the primary object of the thief's interest. ${ }^{9}$

However, the database we use has two deficiencies: (i) Notably, one of the criteria for a theft to qualify as a crime is damage in excess of 5,000 CZK (\$200). Because the data only contains cases known to the police and classified as crimes, this may produce sample selection bias in our results due to a mechanical correlation between metal prices and damage caused, because marginal offenses may become crimes, and enter the data, when prices rise and vice versa. Note, however, that the 5,000 CZK is a sufficient but not necessary condition. For instance, an offense qualifies as a crime irrespective of the damage if the thief broke into an object or had to overcome an obstacle, such as a fence. Thus, many metal thefts recorded by the police probably qualify as crimes irrespective of the damage caused. In fact, 34.6 percent of the thefts in our data involved a break-in. We exploit this information later to check the robustness of our results. (ii) There is no information as to which particular metal was stolen. To proceed without knowing the exact mix of stolen metals, we first had to determine the relevant price index. The existing sources suggest that copper is probably the most frequently stolen of the nonferrous metals (Bennett 2008, 2012a; Kooi 2010; Posick et al. 2012; Sidebottom et al. 2011; Sidebottom, Ashby, and Johnson 2014). Copper price is thus the first candidate.

\footnotetext{
8“Evidenčně statistický systém kriminality" in Czech.

${ }^{9}$ Crimes classified as thefts represent 94.8 percent of all nonferrous metal-related crimes in the data. Primary metal thefts represent 80.0 percent of thefts in the data, that is, in 20 percent of cases the primary object was not metal (the two most frequent primary objects in this category were tools and money). As a robustness check, we also report estimates for all metal-related thefts.
} 
Table 1: Metal thefts in the media: number of articles mentioning individual metals

\begin{tabular}{lcrrrrr}
\hline & Aluminum & Copper & Lead & Nickel & Tin & Zinc \\
\hline Mean & 52.17 & 89.52 & 1.90 & 1.07 & 2.72 & 0.83 \\
Median & 53.00 & 92.50 & 1.00 & 0.00 & 2.00 & 0.00 \\
\hline Correlation with primary metal thefts & 0.02 & $0.87^{*}$ & -0.04 & 0.14 & $-0.19^{+}$ & $0.23^{+}$ \\
& $(0.27)$ & $(19.15)$ & $(-0.43)$ & $(1.53)$ & $(-2.15)$ & $(2.56)$ \\
\hline
\end{tabular}

Note: The unit of observation is a month, data range from January 2003 to December 2012. Primary metal thefts are those with non-ferrous metals as the primary object of the thief's interest. Data source: Anopress.cz. $t$-statistics are in parentheses: ${ }^{+} p<0.05,{ }^{*} p<0.01$.

In order to verify this assumption, we retrieved all newspaper articles that mentioned a metal theft related to aluminum, copper, lead, nickel, tin, and zinc, using media monitoring service Anopress.cz. The means and medians of monthly number of articles reporting thefts of these metals are reported in Table 1. Based on this evidence, the most frequently stolen metal is indeed copper, followed by aluminum; other metals seem to play a much lesser role. We then estimated the Pearson correlation coefficient between the number of metal thefts in the police data and the number of mentions of respective metal theft in media in monthly time series from 2003 and 2012. As reported at the bottom of Table 1, for aluminum, the estimate is $r=0.02$, whereas for copper it is $r=0.87$ ( $t$-statistic 19.15). From this, we believe, it is safe to conclude that copper is the most relevant price component and we therefore use copper price as the main explanatory variable. However, to the extent that a "true price" relevant for the thieves would rather be a price index, possibly with time-varying weights, as thieves may be able to substitute between individual metals to be stolen depending on their market valuation, using only copper introduces a measurement error which is negatively correlated with copper price. This measurement error should result in biasing our coefficients towards zero, making our estimates conservative. ${ }^{10}$

Next, we wanted to ascertain whether the prices Czech metal thieves work with are driven by the world market. For this purpose we collected daily data on metal purchase prices from a scrap yard in Hradec Králové, a town with a population of 90,000 located

\footnotetext{
${ }^{10}$ Intuitively, a decrease in copper price would alter thieves' optimum mix of stolen metals and the weight of copper in the index should decrease; yet our price index keeps it fixed at 100 percent. Keeping the measure fixed thus results in our overestimating the changes in the value of theft opportunities, leading to conservative bias in our regressions. As a robustness check we use an index consisting of copper and aluminum prices, but there is no appreciable change in results (see block $\mathbf{J}$ in Table 6 ).
} 
Table 2: The world market and metal prices at a Czech scrap yard

\begin{tabular}{|c|c|c|c|c|c|c|}
\hline & \multicolumn{6}{|c|}{ Scrap yard prices $(\operatorname{logs})$} \\
\hline & \multicolumn{2}{|c|}{ Copper } & \multicolumn{2}{|c|}{ Aluminum } & \multirow{2}{*}{$\begin{array}{c}\text { Lead } \\
\text { Pieces } \\
(5) \\
\end{array}$} & \multirow{2}{*}{$\begin{array}{c}\text { Zinc } \\
\text { Sheets } \\
(6)\end{array}$} \\
\hline & $\begin{array}{l}\text { Sheets } \\
\text { (1) }\end{array}$ & $\begin{array}{l}\text { Wires } \\
(2)\end{array}$ & $\begin{array}{c}\text { Sheets } \\
\text { (3) }\end{array}$ & $\begin{array}{c}\text { Pieces } \\
(4)\end{array}$ & & \\
\hline LME prices $(\operatorname{logs})$ & & & & & & \\
\hline Copper & $\begin{array}{l}1.03^{*} \\
(0.04)\end{array}$ & $\begin{array}{c}1.03^{*} \\
(0.04)\end{array}$ & & & & \\
\hline Aluminum & & & $\begin{array}{c}1.45^{*} \\
(0.34)\end{array}$ & $\begin{array}{c}1.35^{*} \\
(0.31)\end{array}$ & & \\
\hline Lead & & & & & $\begin{array}{c}0.97^{+} \\
(0.48)\end{array}$ & \\
\hline Zinc & & & & & & $\begin{array}{c}1.03^{+} \\
(0.47)\end{array}$ \\
\hline Constant & $\begin{array}{r}-0.44^{+} \\
(0.19)\end{array}$ & $\begin{array}{c}-0.44^{+} \\
(0.19)\end{array}$ & $\begin{array}{c}-2.48^{+} \\
(1.26)\end{array}$ & $\begin{array}{r}-1.95 \\
(1.16)\end{array}$ & $\begin{array}{c}-0.75 \\
(1.65)\end{array}$ & $\begin{array}{r}-1.10 \\
(1.76)\end{array}$ \\
\hline Observations & 58 & 58 & 58 & 58 & 58 & 58 \\
\hline Adjusted $\mathrm{R}^{2}$ & 0.97 & 0.97 & 0.72 & 0.78 & 0.55 & 0.71 \\
\hline Augm. Dickey-Fuller t. (p-value) & $<0.01$ & $<0.01$ & 0.22 & 0.34 & 0.30 & 0.22 \\
\hline
\end{tabular}

Note: The unit of observation is a month, data range from July 2006 to April 2011.

about $100 \mathrm{~km}$ east of Prague. ${ }^{11}$ The dataset covers the period from July 2006 to April 2011 and contains the prices of copper (sheets and wires), aluminum (sheets and pieces), lead (pieces), and zinc (sheets). We aggregated the data to obtain monthly average prices and merged it with the monthly metal prices at the London Metal Exchange, available from the World Bank's GEM Commodities database, multiplied by the exchange rate. We then ran simple regressions of the scrap yard prices on the LME prices (all in logs). The results, reported in Table 2, show that the world and scrap yard prices of copper are very closely related: a one percent change in copper price at the LME is predicted to change prices at the Czech scrap yard by 1.03 percent (s.e. $0.04, r^{2} 0.97$ ), which is not statistically different from unity. This finding is consistent with earlier results in Aruga and Managi (2011). From this exercise we are confident in concluding that copper prices from the LME can be safely used as a proxy for the prices Czech metal thieves work with.

To obtain the estimation dataset, we aggregate the police data to the monthly level and merge it with the average monthly metal prices at the London Metal Exchange available

\footnotetext{
${ }^{11}$ We contacted and personally visited a number of other scrap yards, however we were not able to obtain any additional data from them. The reason most often given was that the prices change very frequently and they do not keep records. Also, the personnel stated that their prices are determined by the market.
} 
Table 3: Summary statistics

\begin{tabular}{|c|c|c|c|c|c|}
\hline & Mean & St. Dev. & Min & Median & $\operatorname{Max}$ \\
\hline \multicolumn{6}{|l|}{ Metal thefts (primary): } \\
\hline Thefts & 282.0 & 134.7 & 61 & 280 & 516 \\
\hline Damage per theft (1000 CZK) & 36.1 & 10.1 & 21.2 & 34.4 & 82.0 \\
\hline Stolen value per theft (1000 CZK) & 31.1 & 8.3 & 16.9 & 30.4 & 61.6 \\
\hline Detection rate ( $\%$ in 30 days) & 25.7 & 4.7 & 14.8 & 25.2 & 38.4 \\
\hline Copper price $(\mathrm{CZK} / \mathrm{kg})$ & 107.5 & 32.8 & 46.7 & 115.1 & 173.6 \\
\hline Number of stolen bicycles & 526.0 & 236.4 & 167 & 540.5 & 1050 \\
\hline Damage per stolen bicycle (1000 CZK) & 13.7 & 1.3 & 7.7 & 13.6 & 17.6 \\
\hline Number of property crimes & 18419.2 & 1760.7 & 13668 & 18376.5 & 22376 \\
\hline Damage per property crime (1000 CZK) & 39.5 & 7.7 & 17.4 & 39.4 & 83.0 \\
\hline Real wage index $\times 100$ & 132.7 & 9.2 & 116.3 & 135.2 & 149.5 \\
\hline Unemployment rate $(\%)$ & 8.2 & 1.3 & 5.0 & 8.5 & 9.9 \\
\hline Standard \& Poor's 500 Index & 1204.4 & 180.0 & 757.1 & 1212.1 & 1539.7 \\
\hline Air temperature $\left({ }^{\circ} \mathrm{C}\right)$ & 8.3 & 7.5 & -6.0 & 8.2 & 21.4 \\
\hline Rainfall per day (mm) & 1.9 & 1.0 & 0.03 & 1.8 & 4.8 \\
\hline New Criminal Code $(=1)$ & 0.3 & 0.5 & 0 & 0 & 1 \\
\hline \multicolumn{6}{|l|}{ Parliamentary elections: } \\
\hline Year before $(=1)$ & 0.2 & 0.4 & 0 & 0 & 1 \\
\hline Year after $(=1)$ & 0.2 & 0.4 & 0 & 0 & 1 \\
\hline \multicolumn{6}{|l|}{ Regional elections: } \\
\hline Year before $(=1)$ & 0.3 & 0.5 & 0 & 0 & 1 \\
\hline Year after $(=1)$ & 0.2 & 0.4 & 0 & 0 & 1 \\
\hline Number of observations & 120 & & & & \\
\hline
\end{tabular}

Note: The unit of observation is a month, data range from January 2003 to December 2012.

from the World Bank's GEM Commodities database. The prices are then multiplied by the CZK/USD exchange rate and divided by the Czech consumer price index to obtain real prices. To control for potential confounding factors, we merge the data with series on property crimes, stolen bicycles, the monthly unemployment rate, the quarterly average gross wage index (we intrapolate wage data to obtain monthly series), monthly averages of the Standard \& Poor's 500 Index, air temperature, and rainfall. Because a new Criminal Code was introduced in 2010, we also create an indicator variable which is switched on from January 1, 2010 when the law became applicable. Finally, in order to control for the political cycle, which may produce demand-side shocks (Levitt 1997), we create dummies for pre- and post-election years for parliamentary and regional elections. Table 3 summarizes the final dataset. ${ }^{12}$

\footnotetext{
${ }^{12}$ The data and code are available from the authors upon request.
} 


\section{Methodology and Results}

Our empirical model of criminal activity is straightforward: Let $y_{t}$ be the the natural logarithm of the number of primary metal thefts and $p_{t}$ the natural logarithm of average copper price, respectively. Both variables are observed at the monthly level, where $t$ denotes a year-month. As a candidate regression consider

$$
y_{t}=\beta_{0}+\beta_{1} p_{t}+\boldsymbol{\beta}_{\mathbf{2}} \boldsymbol{x}_{t}+\epsilon_{t}
$$

where $\boldsymbol{x}_{\boldsymbol{t}}$ is a vector of control variables, $\beta$ s are parameters to be estimated, and $\epsilon_{t}$ is the residual. The coefficient of interest is $\beta_{1}$, which estimates the elasticity of supply of metal thefts with respect to copper price. Because both $y_{t}$ and $p_{t}$ are non-stationary and integrated of order one, equation (1) is a valid estimator only if $y_{t}$ and $p_{t}$ are cointegrated of order zero (Engle and Granger 1987; Murray 1994). ${ }^{13}$ This happens if there is a linear combination of the series that is stationary and can be ascertained by testing whether the residual series $\epsilon_{t}$ from regression (1) is nonstationary. ${ }^{14}$

\subsection{The Equilibrium Relationship}

Specifications (1) through (6) in Table 4 report alternative estimates of regression (1) with $p$-values of augmented Dickey-Fuller (ADF) tests of nonstationarity of residuals reported at the bottom. With one exception, nonstationarity of the vector of residuals is always rejected at the 5-percent level. This is evidence of the existence of a long-term equilibrium relationship between copper prices and metal thefts, which can be estimated using the levels estimator (1) (Davidson and MacKinnon 2003). Because Durbin-Watson tests always reject the absence of autocorrelation of residuals, as reported at the bottom of Table 4, the reported standard errors were computed the using Newey and West's (1987) estimator, which is robust to heteroskedasticity and autocorrelation.

\footnotetext{
${ }^{13}$ The Augmented Dickey-Fuller test of nonstationarity of the log metal thefts series produces test statistic -2.51 ( $p$-value 0.36) whereas for the first-differenced series the statistic is -5.47 ( $p$-value $<0.01$ ). For the series of log copper prices the test yields statistic -2.40 ( $p$-value 0.41$)$ whereas for the first differenced series it is -4.30 ( $p$-value $<0.01)$.

${ }^{14}$ See Davidson and MacKinnon (2003, ch. 14.6) for an overview and discussion of testing for cointegration.
} 
Table 4: Levels estimates of the effect of copper prices on nonferrous metal thefts

\begin{tabular}{|c|c|c|c|c|c|c|c|c|c|c|c|c|}
\hline & (1) & (2) & (3) & (4) & (5) & (6) & (7) & (8) & (9) & (10) & (11) & (12) \\
\hline Log copper price & $\begin{array}{r}1.34^{*} \\
(0.18)\end{array}$ & $\begin{array}{c}1.40^{*} \\
(0.16)\end{array}$ & $\begin{array}{r}1.34^{*} \\
(0.13)\end{array}$ & $\begin{array}{c}1.05^{*} \\
(0.11)\end{array}$ & $\begin{array}{r}1.05^{*} \\
(0.09)\end{array}$ & $\begin{array}{c}0.90^{*} \\
(0.12)\end{array}$ & $\begin{array}{c}1.41^{*} \\
(0.19)\end{array}$ & $\begin{array}{c}1.49^{*} \\
(0.15)\end{array}$ & $\begin{array}{c}1.47^{*} \\
(0.11)\end{array}$ & $\begin{array}{c}1.09^{*} \\
(0.17)\end{array}$ & $\begin{array}{c}1.10^{*} \\
(0.17)\end{array}$ & $\begin{array}{c}1.00^{*} \\
(0.21)\end{array}$ \\
\hline Log stolen bicycles & & $\begin{array}{c}0.47 \\
(0.27)\end{array}$ & $\begin{array}{c}0.07 \\
(0.27)\end{array}$ & $\begin{array}{c}0.31 \\
(0.16)\end{array}$ & $\begin{array}{c}0.31 \\
(0.16)\end{array}$ & $\begin{array}{c}0.32^{+} \\
(0.13)\end{array}$ & & $\begin{array}{c}0.65^{+} \\
(0.25)\end{array}$ & $\begin{array}{c}0.08 \\
(0.23)\end{array}$ & $\begin{array}{c}0.23 \\
(0.24)\end{array}$ & $\begin{array}{c}0.27 \\
(0.27)\end{array}$ & $\begin{array}{c}0.22 \\
(0.24)\end{array}$ \\
\hline Log property crimes & & $\begin{array}{c}0.51 \\
(0.48)\end{array}$ & $\begin{array}{c}1.51^{+} \\
(0.69)\end{array}$ & $\begin{array}{c}1.28^{*} \\
(0.38)\end{array}$ & $\begin{array}{c}1.21^{*} \\
(0.39)\end{array}$ & $\begin{array}{c}0.89^{*} \\
(0.30)\end{array}$ & & $\begin{array}{c}0.71 \\
(0.60)\end{array}$ & $\begin{array}{c}1.82^{*} \\
(0.60)\end{array}$ & $\begin{array}{c}0.95 \\
(0.84)\end{array}$ & $\begin{array}{c}0.95 \\
(0.87)\end{array}$ & $\begin{array}{c}-0.33 \\
(0.75)\end{array}$ \\
\hline Lagged detection rate (\% in 30 days) & & & $\begin{array}{c}-0.01 \\
(0.01)\end{array}$ & $\begin{array}{r}0.003 \\
(0.01)\end{array}$ & $\begin{array}{r}0.005 \\
(0.01)\end{array}$ & $\begin{array}{c}0.01 \\
(0.01)\end{array}$ & & & $\begin{array}{c}-0.01 \\
(0.01)\end{array}$ & $\begin{array}{r}0.005 \\
(0.01)\end{array}$ & $\begin{array}{c}0.005 \\
(0.01)\end{array}$ & $\begin{array}{c}0.04^{+} \\
(0.02)\end{array}$ \\
\hline New Criminal Code $(=1)$ & & & $\begin{array}{c}0.30^{+} \\
(0.13)\end{array}$ & $\begin{array}{c}0.49^{*} \\
(0.12)\end{array}$ & $\begin{array}{c}0.50^{*} \\
(0.12)\end{array}$ & $\begin{array}{c}0.37^{*} \\
(0.08)\end{array}$ & & & $\begin{array}{c}0.30^{*} \\
(0.09)\end{array}$ & $\begin{array}{c}0.42^{*} \\
(0.15)\end{array}$ & $\begin{array}{c}0.41^{*} \\
(0.15)\end{array}$ & $\begin{array}{c}0.15 \\
(0.11)\end{array}$ \\
\hline Unemployment rate (\%) & & & & $\begin{array}{r}-0.14^{*} \\
(0.04)\end{array}$ & $\begin{array}{r}-0.14^{*} \\
(0.03)\end{array}$ & $\begin{array}{r}-0.11^{*} \\
(0.03)\end{array}$ & & & & $\begin{array}{c}-0.11^{+} \\
(0.05)\end{array}$ & $\begin{array}{c}-0.11^{+} \\
(0.05)\end{array}$ & $\begin{array}{c}-0.07^{+} \\
(0.03)\end{array}$ \\
\hline Real wage index $\times 100$ & & & & $\begin{array}{r}-0.005 \\
(0.01)\end{array}$ & $\begin{array}{c}-0.01 \\
(0.01)\end{array}$ & $\begin{array}{c}0.001 \\
(0.01)\end{array}$ & & & & $\begin{array}{r}-0.001 \\
(0.01)\end{array}$ & $\begin{array}{r}-0.001 \\
(0.01)\end{array}$ & $\begin{array}{c}0.01^{+} \\
(0.01)\end{array}$ \\
\hline $\log \mathrm{S} \& \mathrm{P} 500$ & & & & $\begin{array}{c}0.44 \\
(0.24)\end{array}$ & $\begin{array}{c}0.42 \\
(0.24)\end{array}$ & $\begin{array}{c}0.58^{*} \\
(0.20)\end{array}$ & & & & $\begin{array}{c}0.35 \\
(0.38)\end{array}$ & $\begin{array}{c}0.32 \\
(0.40)\end{array}$ & $\begin{array}{c}0.47 \\
(0.41)\end{array}$ \\
\hline Log rainfall & & & & & $\begin{array}{c}0.02 \\
(0.02)\end{array}$ & $\begin{array}{c}0.03 \\
(0.02)\end{array}$ & & & & & $\begin{array}{c}0.01 \\
(0.02)\end{array}$ & $\begin{array}{c}0.01 \\
(0.02)\end{array}$ \\
\hline Air temperature $\left({ }^{\circ} \mathrm{C}\right)$ & & & & & $\begin{array}{c}0.02^{+} \\
(0.01)\end{array}$ & $\begin{array}{c}0.02^{+} \\
(0.01)\end{array}$ & & & & & $\begin{array}{c}-0.004 \\
(0.01)\end{array}$ & $\begin{array}{c}-0.004 \\
(0.01)\end{array}$ \\
\hline \multicolumn{13}{|l|}{ Parliamentary elections: } \\
\hline Year before & & & & & & $\begin{array}{c}-0.09^{+} \\
(0.04)\end{array}$ & & & & & & $\begin{array}{c}-0.27^{*} \\
(0.06)\end{array}$ \\
\hline Year after & & & & & & $\begin{array}{c}-0.01 \\
(0.05)\end{array}$ & & & & & & $\begin{array}{c}-0.01 \\
(0.06)\end{array}$ \\
\hline \multicolumn{13}{|l|}{ Regional elections: } \\
\hline Year before & & & & & & $\begin{array}{c}-0.10^{+} \\
(0.04)\end{array}$ & & & & & & $\begin{array}{c}-0.05 \\
(0.04)\end{array}$ \\
\hline Year after & & & & & & $\begin{array}{r}-0.13^{*} \\
(0.04)\end{array}$ & & & & & & $\begin{array}{c}-0.11^{+} \\
(0.05)\end{array}$ \\
\hline Constant & $\begin{array}{c}-0.64 \\
(0.83)\end{array}$ & $\begin{array}{c}-8.43 \\
(4.54)\end{array}$ & $\begin{array}{r}-15.72^{+} \\
(6.24)\end{array}$ & $\begin{array}{r}-15.13^{*} \\
(4.63)\end{array}$ & $\begin{array}{r}-14.23^{*} \\
(4.66)\end{array}$ & $\begin{array}{r}-12.56^{*} \\
(3.62)\end{array}$ & $\begin{array}{c}-1.02 \\
(0.87)\end{array}$ & $\begin{array}{r}-12.00 \\
(6.81)\end{array}$ & $\begin{array}{r}-19.29^{*} \\
(5.94)\end{array}$ & $\begin{array}{c}-11.69 \\
(10.89) \\
\end{array}$ & $\begin{array}{c}-11.65 \\
(11.22) \\
\end{array}$ & $\begin{array}{c}-2.11 \\
(9.14)\end{array}$ \\
\hline Month effects & Yes & Yes & Yes & Yes & Yes & Yes & Yes & Yes & Yes & Yes & Yes & Yes \\
\hline DOLS & - & - & - & - & - & - & Yes & Yes & Yes & Yes & Yes & Yes \\
\hline $\begin{array}{l}\text { Observations } \\
\text { Adiusted } R^{2}\end{array}$ & $\begin{array}{r}120 \\
0.80\end{array}$ & $\begin{array}{r}120 \\
0.82\end{array}$ & $\begin{array}{r}119 \\
0.85\end{array}$ & $\begin{array}{r}119 \\
0.92\end{array}$ & $\begin{array}{r}119 \\
0.92\end{array}$ & $\begin{array}{r}119 \\
0.93\end{array}$ & $\begin{array}{l}115 \\
0.88\end{array}$ & $\begin{array}{c}115 \\
0.90\end{array}$ & $\begin{array}{r}114 \\
0.92\end{array}$ & $\begin{array}{l}114 \\
0.94\end{array}$ & $\begin{array}{l}114 \\
0.94\end{array}$ & $\begin{array}{l}114 \\
0.96\end{array}$ \\
\hline $\begin{array}{l}\text { Adjusted R² } \\
\text { Angm Dicke }\end{array}$ & 0.00 & & & 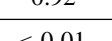 & -0.25 & -0.01 & & $\frac{0.000}{0.90}$ & & 0.94 & -0.01 & \\
\hline $\begin{array}{l}\text { Augm. Dickey-Fuller t. (p-valt } \\
\text { Durbin-Watson test (p-value) }\end{array}$ & $\begin{array}{l}0.047 \\
0.000\end{array}$ & 0.000 & $\begin{array}{l}0.068 \\
0.000\end{array}$ & $\begin{array}{r}<0.01 \\
0.000\end{array}$ & $\begin{aligned}<0.01 \\
0.000\end{aligned}$ & $\begin{array}{r}<0.01 \\
0.011\end{array}$ & $\begin{array}{l}0.078 \\
0.000\end{array}$ & $\begin{array}{l}0.020 \\
0.000\end{array}$ & $\begin{array}{r}<0.01 \\
0.000\end{array}$ & $\begin{array}{c}<0.01 \\
0.000\end{array}$ & $\begin{array}{c}<0.01 \\
0.000\end{array}$ & $\begin{aligned}<0.01 \\
0.047\end{aligned}$ \\
\hline
\end{tabular}

Note: The outcome variable is the logarithm of the average number of thefts involving nonferrous metals as the primary object per day in a month. Data range from January 2003 to December 2012 . DOLS specifications inclide 
Specification (1) reports the results of a simple regression of metal thefts on copper price and a full set of month dummies to control for seasonal regularities and the number of days in a month. The coefficient estimate on copper price suggests that the price elasticity of the supply of offenses is 1.34 , and with the estimated standard error of 0.14 this is statistically significant at an arbitrary level.

In order to control for general crime trends and potential substitution between metal theft and other criminal activities due to shocks in the (relative) value of metal theft opportunities (as opposed to substitution between legitimate and illegitimate activity), specification (2) includes the number of property crimes and the number of stolen bicycles in each month, both are in logs. ${ }^{15}$ Although the available empirical evidence on substitution across criminal activities is inconclusive, ${ }^{16}$ we hypothesize that stealing a bicycle is a relatively close alternative to metal theft; since bicycle thefts are comparable to metal thefts in terms of the sophistication required as well as in terms of the frequency and the damage caused (see Table 3). Bicycle thefts are unlikely, though, to be (directly) driven by metal prices, since bicycles are typically stolen to be resold on the used bicycle market rather than to a scrap yard. Controlling for property and bicycle thefts does not appreciably change the estimated elasticity, however.

Specification (3) adds a lagged clearance rate, that is the percentage of thieves detected by the police in the previous period, and a dummy for the 2010 Criminal Code. The coefficient estimates on these controls should be read with caution as the detection rate is likely to be influenced by criminal activity and the new Criminal Code did not bring about any substantive change in the treatment of thefts. Notwithstanding those concerns,

\footnotetext{
${ }^{15}$ The two series are plotted in Figure A1 in the Appendix. We note that it is not clear whether property crime should be controlled for or not. It is possible that that offenders may substitute metal thefts and other property, depending on their relative valuation. In that case, property crimes would be affected by copper prices, and regressions controlling for property crimes would underestimate the effect of prices on metal thefts. Note, however, that the average number of property crimes per month in our data is 18,400 while the average number of metal thefts is 280 , so the bulk of variation in property crime will probably be unrelated to substitution from metal thefts (see Table 3). More importantly, one might argue that not including property crimes would lead to overestimating the effect of prices on thefts, as new metal thefts may represent substitutes for other opportunities and not new crimes. We lean towards the latter approach and prefer the regressions controlling for property crimes and bicycle theft in order to net out these potential substitution effects and control for general crime trends. We further delve the issue of substitution in Section 4.2 .

${ }^{16}$ See, e.g., Ayres and Donohue (2003); Cameron (1987); Detotto and Pulina (2013); Koskela and Viren (1997); Levitt (1998); and Lott and Mustard (1997).
} 
the coefficient estimate on log copper price is the same as in specification (1) and is not statistically different from the estimate in specification (2).

To control for general economic shocks that may affect metal thefts, specification (4) includes the unemployment rate, the real wage index, and the Standard \& Poor's 500 index. These controls are potentially problematic, as economic shocks are likely to affect demand for metals and thus metal prices. This is consistent with the negative coefficient estimate on unemployment and positive estimate on S\&P 500, which are the opposite signs from those one would expect if criminal activity was countercyclical (Cook and Zarkin 1985; Cook 2010). This suggests we are 'overcontrolling' in this specification and the price elasticity of metal thefts is underestimated. However if we instead control for the business cycle then the estimated elasticity is equal to unity and is highly statistically significant. Less controversially, specifications (5) and (6) control for weather shocks and the political cycle. Weather does not alter, the results but controlling for pre- and post-election years results in a small decline in the estimate of the elasticity to about 0.90 . This result is not statistically different from our estimates in specifications (4) and (5).

Because levels estimators in small samples may be biased and are inefficient, we have also estimated dynamic OLS (DOLS) models that have been shown to yield unbiased estimates of the cointegrating relationship (Saikkonen 1991; Stock and Watson 1993). The DOLS estimates are obtained by augmenting the levels estimators with the first differences of the explanatory variables and two leads and lags of differenced explanatory variables. ${ }^{17}$ We re-estimate DOLS models for specifications (1) through (6) in Table 4. The results are reported in columns (7) through (12) and the estimates of elasticities are qualitatively similar to the simple levels models estimates, albeit slightly higher. To summarize, we provide a range of estimates and leave it to readers to assess which model is preferable. The results of the 12 alternative regression estimates reported in Table 4 strongly suggest that the price elasticity of the supply of metal thefts is greater than zero and most likely lies between unity and 1.5.

\footnotetext{
${ }^{17}$ The choice of leads and lags follows Stock and Watson (1993) who, in their Monte Carlo simulations, used two leads and lags for samples of size 100; our sample size is 120. Using different a number of leads and lags yields qualitatively similar results (see Table 6).
} 


\subsection{Short-Term Corrections}

Cointegration evidences a long-term equilibrium relationship between between copper price and metal thefts. This means that necessarily a mechanism exists to absorb shocks and correct transitory deviations from that equilibrium (Engle and Granger 1987; Murray 1994). This error-correction mechanism (ECM) can be expressed as

$$
E\left(y_{t}-y_{t-1}\right)=\gamma_{1} \epsilon_{t-1}+\gamma_{\mathbf{2}}^{\prime}\left(\boldsymbol{x}_{t-1}-\boldsymbol{x}_{t-2}\right),
$$

where $\epsilon_{t-1}$ is the distance between the realized level of $y$ and its equilibrium value in the period $t-1$. In plain words, the expected change in $y$ in the current period depends on its deviation from the equilibrium at the beginning of the period and real shocks in the previous period. The coefficient $\gamma_{1}$ is then the error-correction term capturing the speed with which the system equilibriates and is predicted to have a negative sign. The vector $\gamma_{2}$ captures the short-term reaction of $y$ to shocks in the explanatory variables. Because the residual series from levels regressions estimate the equilibrium error in each period, equation (3) can be estimated directly as

$$
y_{t}-y_{t-1}=\gamma_{1} \hat{\epsilon}_{t-1}+\gamma_{2}^{\prime}\left(\boldsymbol{x}_{t-1}-\boldsymbol{x}_{t-2}\right)+e_{t}
$$

where $\hat{\epsilon}_{t}$ is the residual series from regression (1) and $e_{t}$ is an error term.

Table 5 reports the results of ECM models analogous to specifications (1) through (5) and (7) through (11) in Table 4. ${ }^{18}$ The first row reports estimates on the respective error correction terms. For models (1) through (5) in Table 5 the equilibrium error term is the residual series from the respective regressions in Table 4. Models (6) through (10) include the residual series from the respective DOLS models. Both sets of estimates yield comparable results. The coefficient estimates for the error-correction term are between -0.28 and -0.59 and are always highly statistically significant. These numbers suggest that a disequilibriating shock is corrected within two to four months. The second row of

\footnotetext{
${ }^{18}$ Note that the ECM models do not include dummies for the new Criminal Code and pre- and post-election years, as there would be no sensible interpretation of coefficients estimates on differenced dummies in ECM regressions.
} 
Table 5: Error-correction models of copper prices and nonferrous metal thefts

\begin{tabular}{|c|c|c|c|c|c|c|c|c|c|c|}
\hline & (1) & (2) & (3) & (4) & $(5)$ & (6) & (7) & (8) & (9) & (10) \\
\hline Lagged residuals from levels models & $\begin{array}{r}-0.28^{*} \\
(0.05)\end{array}$ & $\begin{array}{r}-0.28^{*} \\
(0.06)\end{array}$ & $\begin{array}{r}-0.34^{*} \\
(0.06)\end{array}$ & $\begin{array}{r}-0.41^{*} \\
(0.08)\end{array}$ & $\begin{array}{r}-0.40^{*} \\
(0.09)\end{array}$ & $\begin{array}{c}-0.30^{*} \\
(0.06)\end{array}$ & $\begin{array}{r}-0.32^{*} \\
(0.07)\end{array}$ & $\begin{array}{r}-0.38^{*} \\
(0.09)\end{array}$ & $\begin{array}{r}-0.59^{*} \\
(0.11)\end{array}$ & $\begin{array}{r}-0.49^{*} \\
(0.11)\end{array}$ \\
\hline \multicolumn{11}{|l|}{ Lagged differences: } \\
\hline Log copper price & $\begin{array}{c}0.49 \\
(0.33)\end{array}$ & $\begin{array}{c}0.48 \\
(0.31)\end{array}$ & $\begin{array}{c}0.46 \\
(0.29)\end{array}$ & $\begin{array}{c}0.53 \\
(0.28)\end{array}$ & $\begin{array}{r}0.62^{*} \\
(0.24)\end{array}$ & $\begin{array}{c}0.97^{*} \\
(0.30)\end{array}$ & $\begin{array}{c}1.00^{*} \\
(0.29)\end{array}$ & $\begin{array}{c}0.98^{*} \\
(0.29)\end{array}$ & $\begin{array}{c}0.88^{*} \\
(0.26)\end{array}$ & $\begin{array}{c}0.93^{*} \\
(0.22)\end{array}$ \\
\hline Log stolen bicycles & & $\begin{array}{r}-0.30^{+} \\
(0.14)\end{array}$ & $\begin{array}{r}-0.20 \\
(0.13)\end{array}$ & $\begin{array}{c}-0.24 \\
(0.14)\end{array}$ & $\begin{array}{r}-0.09 \\
(0.13)\end{array}$ & & $\begin{array}{c}-0.27^{+} \\
(0.13)\end{array}$ & $\begin{array}{c}-0.29^{+} \\
(0.14)\end{array}$ & $\begin{array}{c}-0.27^{+} \\
(0.13)\end{array}$ & $\begin{array}{r}-0.11 \\
(0.13)\end{array}$ \\
\hline Log property crimes & & $\begin{array}{c}0.20 \\
(0.33)\end{array}$ & $\begin{array}{c}-0.08 \\
(0.30)\end{array}$ & $\begin{array}{c}-0.05 \\
(0.32)\end{array}$ & $\begin{array}{c}-0.04 \\
(0.28)\end{array}$ & & $\begin{array}{c}0.17 \\
(0.32)\end{array}$ & $\begin{array}{c}0.18 \\
(0.30)\end{array}$ & $\begin{array}{c}0.16 \\
(0.28)\end{array}$ & $\begin{array}{c}0.16 \\
(0.26)\end{array}$ \\
\hline Lagged detection rate ( $\%$ in 30 days) & & & $\begin{array}{c}0.002 \\
(0.003)\end{array}$ & $\begin{array}{c}0.0002 \\
(0.003)\end{array}$ & $\begin{array}{c}0.001 \\
(0.003)\end{array}$ & & & $\begin{array}{c}0.001 \\
(0.003)\end{array}$ & $\begin{array}{c}0.001 \\
(0.003)\end{array}$ & $\begin{array}{c}0.001 \\
(0.003)\end{array}$ \\
\hline Unemployment rate $(\%)$ & & & & $\begin{array}{c}-0.01 \\
(0.09)\end{array}$ & $\begin{array}{c}-0.05 \\
(0.08)\end{array}$ & & & & $\begin{array}{c}0.02 \\
(0.08)\end{array}$ & $\begin{array}{c}-0.01 \\
(0.07)\end{array}$ \\
\hline Real wage index $\times 100$ & & & & $\begin{array}{c}0.02 \\
(0.02)\end{array}$ & $\begin{array}{c}0.002 \\
(0.02)\end{array}$ & & & & $\begin{array}{c}-0.0000 \\
(0.02)\end{array}$ & $\begin{array}{c}-0.01 \\
(0.02)\end{array}$ \\
\hline Log S\&P 500 & & & & $\begin{array}{c}0.61 \\
(0.47)\end{array}$ & $\begin{array}{c}0.68 \\
(0.45)\end{array}$ & & & & $\begin{array}{c}0.33 \\
(0.48)\end{array}$ & $\begin{array}{c}0.40 \\
(0.47)\end{array}$ \\
\hline Log rainfall & & & & & $\begin{array}{c}0.01 \\
(0.01)\end{array}$ & & & & & $\begin{array}{c}0.01 \\
(0.01)\end{array}$ \\
\hline Air temperature $\left({ }^{\circ} \mathrm{C}\right)$ & & & & & $\begin{array}{r}0.02^{*} \\
(0.01)\end{array}$ & & & & & $\begin{array}{c}0.02^{*} \\
(0.01)\end{array}$ \\
\hline Constant & $\begin{array}{c}0.52^{*} \\
(0.07)\end{array}$ & $\begin{array}{r}0.39^{*} \\
(0.08)\end{array}$ & $\begin{array}{c}0.41^{*} \\
(0.09)\end{array}$ & $\begin{array}{c}0.34^{*} \\
(0.10)\end{array}$ & $\begin{array}{r}0.50^{*} \\
(0.09)\end{array}$ & $\begin{array}{c}0.52^{*} \\
(0.07)\end{array}$ & $\begin{array}{c}0.41^{*} \\
(0.08)\end{array}$ & $\begin{array}{c}0.39^{*} \\
(0.09)\end{array}$ & $\begin{array}{c}0.38^{*} \\
(0.10)\end{array}$ & $\begin{array}{c}0.53^{*} \\
(0.10)\end{array}$ \\
\hline Month effects & Yes & Yes & Yes & Yes & Yes & Yes & Yes & Yes & Yes & Yes \\
\hline Error correction terms from DOLS & - & - & - & - & - & Yes & Yes & Yes & Yes & Yes \\
\hline Observations & 118 & 118 & 117 & 117 & 117 & 115 & 115 & 114 & 114 & 114 \\
\hline Adjusted $\mathrm{R}^{2}$ & 0.71 & 0.71 & 0.73 & 0.72 & 0.76 & 0.71 & 0.71 & 0.71 & 0.72 & 0.75 \\
\hline Augm. Dickey-Fuller t. (p-value) & $<0.01$ & $<0.01$ & $<0.01$ & $<0.01$ & $<0.01$ & $<0.01$ & $<0.01$ & $<0.01$ & $<0.01$ & $<0.01$ \\
\hline Durbin-Watson test (p-value) & 0.861 & 0.986 & 0.507 & 1.000 & 0.838 & 0.251 & 0.433 & 0.447 & 0.758 & 0.517 \\
\hline
\end{tabular}

Note: The outcome variable is the month-to-month difference of the logarithm of the average number of metal thefts per day. Data range from January 2003 to December 2012. DOLS specifications include residuals from respective DOLS models in Table 4. P-values of Augmented Dickey-Fuller below 0.01 are reported as $<0.01$. Heteroskedasticity and autocorrelation robust standard errors (Newey and West 1987) are in parentheses: ${ }^{+} p<0.05,{ }^{*} p<0.01$. 
Table 5 reports estimates of the short-term (monthly) price elasticity of the supply of metal thefts. The results for the OLS models suggest that the short-term elasticity is around 0.5, with one exception; however, these estimates are only marginally statistically significant. Models with the error term from the DOLS specifications produce estimates of short-term elasticity between 0.9 and unity and all these estimates are highly statistically significant. We note that, to the extent that DOLS levels models are preferable, ECM models that include equilibrium error terms estimated by DOLS should be preferred as well.

\section{Alternative Explanations and Robustness Checks}

\subsection{Gauging Selection Concerns}

As noted in Section 2, one of the criteria for an offense to be qualified as a crime is that the damage is 'non-negligible', which in practice means it should exceed 5,000 CZK. This has two potentially important implications: (i) Because the cost of committing a crime is discontinuous at the threshold, individuals have incentives to avoid exceeding it. As a result, a rise in the copper price may lead to an increased number of 'sub-crime' level thefts. Unless some other crime-qualifying condition is met, these thefts do not qualify as crime and are not recorded in the crime database. This may imply that our estimates of the elasticity of supply of offenses may be too conservative. (ii) More worrying, however, is the fact that the damage metal thefts cause and the value of the stolen material are linked to metal prices - if metal prices rise, a specific theft is likely to be associated with greater damage and vice versa. This is problematic because it means the number of crimes may change purely mechanically as offenses at the margin become crimes when prices rise. This would in turn mean that we would be overestimating criminals' reactions to prices.

Being conservative and assuming that prices are fully reflected in the claimed damage and thieves have no control over the extent of the damage they cause, then if thieves do not react to prices, one would expect that the distribution of damage caused simply shifts up and down with prices. Damage distributions by year are plotted in Figure 2. The boxplots are overlaid with jitter, with each point representing damage associated with an individual 
metal theft. Darker parts of the plot suggest a higher frequency of thefts at the respective damage level. It is visually apparent that years with a higher number of recorded crimes saw a rise across the whole spectrum of damage, rather than simply a shift upwards. Also means and medians are quite stable across years and the lower hinges are always above the 5,000 CZK threshold, suggesting that over 75 percent of crimes in the data result in damage above the threshold. Thus, it is unlikely that prices interacting with the threshold explain the almost 250 percent increase in thefts between 2003 and 2011 (the years with minimum and maximum number of metal thefts, respectively). ${ }^{19}$

Nevertheless, this graphical evidence cannot rule out the concern that our main estimates overstate the effect of prices on crime. If the mechanical relationship between copper price and damage is important, there should be a positive relationship between the copper price and the average damage per crime. To test this prediction formally, we regress the log of average damage per crime on copper price and other explanatory variables using the specifications from Table 4. The results are reported in block A of Table 6 and suggest that the relationship is actually negative, although it is substantively small and statistically significant in only four out of 12 specifications. ${ }^{20}$ Block B reports coefficients on log copper price in specifications where the outcome is replaced by the log average value of stolen goods per theft. The results are qualitatively very similar; the relationship between copper price and the average value of stolen material is consistently negative. This finding may seem surprising and, perhaps, counterintuitive. However, a possible explanation is that marginal crimes are likely to be those with low value and marginal thieves are likely to be those with low-value theft opportunities. Put differently, high-value thefts are likely to be undertaken at a wide range of copper prices. So, if the copper price increases, new thefts, if any, will more often be low-value marginal thefts. And if the copper price goes down, low-value theft opportunities will not be exploited, as they are no longer worth it. This result thus supports our hypothesis, that thieves react to changes in the value of criminal opportunities.

\footnotetext{
${ }^{19}$ Probability distributions and cumulative distributions of damage from recorded crimes by year are available in Figure A2 in the Appendix.

${ }^{20}$ Note that using the 10 percent level, the augmented Dickey-Fuller tests fail to reject nonstationarity of residuals from specifications (1) and (7), so these results should be interpreted with caution.
} 


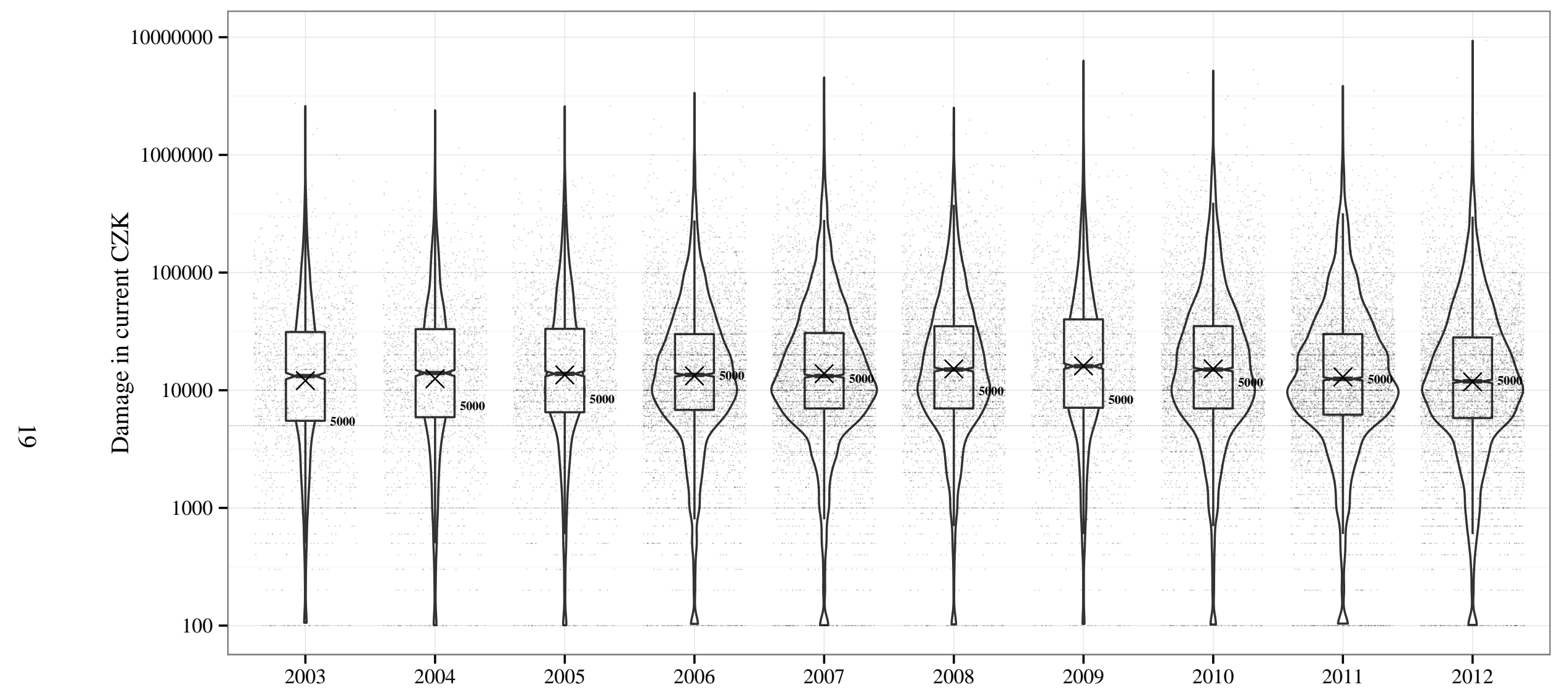

Figure 2: Damage distributions by year, logarithmic scale (damage below $10 \mathrm{CZK}$ coded as 10 to save space). Plots are overlaid with jitter, with each point representing damage associated with an individual metal theft. Contours of violins represent kernel densities, with bandwidth selected according to the Sheather and Jones's (1991) algorithm (Jones, Marron, and Sheather 1996). Slanted crosses mark means. The upper and lower 'hinges' of boxplots correspond to the 25th and 75th percentiles. The upper (lower) whisker extends from the hinge to the highest (lowest) value that is within $1.5 \times I Q R$ of the hinge, where $I Q R$ is the distance between the 25 th and 75 th percentiles. The notches extend $1.58 \times I Q R / \sqrt{n}$, where $n$ is the number of observations, roughly a 95 percent confidence interval for comparing medians (McGill, Tukey, and Larsen 1978). The 5,000 series in the bottom plot denotes the value of the damage associated with a hypothetical theft with damage worth 5,000 CZK-damage in 2003 prices. The value of that damage in the following years was computed assuming that the value of stolen copper is 80 percent of the damage (i.e. 80 percent of the damage was adjusted to reflect the changes in copper price and 20 percent was adjusted by the consumer price index). 
Table 6: Gauging the selection concerns and further robustness checks

\begin{tabular}{|c|c|c|c|c|c|c|c|c|c|c|c|c|c|}
\hline & & (1) & (2) & (3) & (4) & (5) & (6) & (7) & (8) & (9) & (10) & (11) & $(12)$ \\
\hline A: & Outcome replaced by log of mean damage & $\begin{array}{c}-0.08 \\
(0.08) \\
{[0.38]}\end{array}$ & $\begin{array}{c}-0.18^{+} \\
(0.07) \\
{[0.16]}\end{array}$ & $\begin{array}{c}-0.17^{*} \\
(0.07) \\
{[0.19]}\end{array}$ & $\begin{array}{c}-0.06 \\
(0.13) \\
{[0.01]}\end{array}$ & $\begin{array}{c}-0.05 \\
(0.14) \\
{[0.01]}\end{array}$ & $\begin{array}{c}-0.04 \\
(0.16) \\
{[0.01]}\end{array}$ & $\begin{array}{c}-0.12 \\
(0.11) \\
{[0.65]}\end{array}$ & $\begin{array}{c}-0.26^{+} \\
(0.10) \\
{[0.44]}\end{array}$ & $\begin{array}{r}-0.35^{*} \\
(0.07) \\
{[0.46]}\end{array}$ & $\begin{array}{c}-0.32 \\
(0.25) \\
{[0.01]}\end{array}$ & $\begin{array}{c}-0.34 \\
(0.27) \\
{[0.01]}\end{array}$ & $\begin{array}{c}-0.04 \\
(0.39) \\
{[0.01]}\end{array}$ \\
\hline B: & Outcome replaced by log of mean stolen value & $\begin{array}{c}-0.13^{+} \\
(0.06) \\
{[0.56]}\end{array}$ & $\begin{array}{c}-0.17^{*} \\
(0.05) \\
{[0.36]}\end{array}$ & $\begin{array}{c}-0.18^{*} \\
(0.05) \\
{[0.35]}\end{array}$ & $\begin{array}{c}-0.15 \\
(0.14) \\
{[0.01]}\end{array}$ & $\begin{array}{c}-0.15 \\
(0.14) \\
{[0.01]}\end{array}$ & $\begin{array}{c}-0.16 \\
(0.15) \\
{[0.01]}\end{array}$ & $\begin{array}{c}-0.17^{+} \\
(0.08) \\
{[0.57]}\end{array}$ & $\begin{array}{c}-0.23^{*} \\
(0.07) \\
{[0.38]}\end{array}$ & $\begin{array}{c}-0.29^{*} \\
(0.07) \\
{[0.42]}\end{array}$ & $\begin{array}{c}-0.41 \\
(0.28) \\
{[0.02]}\end{array}$ & $\begin{array}{c}-0.44 \\
(0.26) \\
{[0.02]}\end{array}$ & $\begin{array}{c}-0.17 \\
(0.36) \\
{[0.01]}\end{array}$ \\
\hline $\mathrm{C}:$ & Total damage less than $5,000 \mathrm{CZK}^{\mathrm{a}}$ & $\begin{array}{c}1.11^{*} \\
(0.20) \\
{[0.20]}\end{array}$ & $\begin{array}{l}1.15^{*} \\
(0.16) \\
{[0.04]}\end{array}$ & $\begin{array}{c}1.09^{*} \\
(0.12) \\
{[0.05]}\end{array}$ & $\begin{array}{c}0.88^{*} \\
(0.20) \\
{[0.01]}\end{array}$ & $\begin{array}{c}0.87^{*} \\
(0.19) \\
{[0.01]}\end{array}$ & $\begin{array}{c}0.91^{*} \\
(0.22) \\
{[0.01]}\end{array}$ & $\begin{array}{l}1.21^{*} \\
(0.21) \\
{[0.38]}\end{array}$ & $\begin{array}{l}1.26^{*} \\
(0.18) \\
{[0.01]}\end{array}$ & $\begin{array}{l}1.31^{*} \\
(0.11) \\
{[0.02]}\end{array}$ & $\begin{array}{c}1.20^{*} \\
(0.34) \\
{[0.01]}\end{array}$ & $\begin{array}{c}1.23^{*} \\
(0.35) \\
{[0.01]}\end{array}$ & $\begin{array}{c}1.09^{*} \\
(0.36) \\
{[0.01]}\end{array}$ \\
\hline D: & Value of stolen material less than $5,000 \mathrm{CZK}^{\mathrm{b}}$ & $\begin{array}{c}1.27^{*} \\
(0.18) \\
{[0.09]}\end{array}$ & $\begin{array}{c}1.27^{*} \\
(0.15) \\
{[0.07]}\end{array}$ & $\begin{array}{l}1.20^{*} \\
(0.13) \\
{[0.09]}\end{array}$ & $\begin{array}{c}0.92^{*} \\
(0.15) \\
{[0.01]}\end{array}$ & $\begin{array}{c}0.93^{*} \\
(0.15) \\
{[0.01]}\end{array}$ & $\begin{array}{c}0.86^{*} \\
(0.18) \\
{[0.01]}\end{array}$ & $\begin{array}{c}1.38^{*} \\
(0.18) \\
{[0.24]}\end{array}$ & $\begin{array}{c}1.39^{*} \\
(0.16) \\
{[0.04]}\end{array}$ & $\begin{array}{c}1.38^{*} \\
(0.11) \\
{[0.01]}\end{array}$ & $\begin{array}{c}1.10^{*} \\
(0.29) \\
{[0.01]}\end{array}$ & $\begin{array}{c}1.14^{*} \\
(0.31) \\
{[0.01]}\end{array}$ & $\begin{array}{c}0.99^{*} \\
(0.29) \\
{[0.01]}\end{array}$ \\
\hline $\mathrm{E}:$ & Value of stolen material equal to zero ${ }^{c}$ & $\begin{array}{c}1.71^{*} \\
(0.24) \\
{[0.02]}\end{array}$ & $\begin{array}{c}1.66^{*} \\
(0.25) \\
{[0.05]}\end{array}$ & $\begin{array}{c}1.58^{*} \\
(0.24) \\
{[0.06]}\end{array}$ & $\begin{array}{c}1.12^{*} \\
(0.29) \\
{[0.01]}\end{array}$ & $\begin{array}{c}1.14^{*} \\
(0.29) \\
{[0.01]}\end{array}$ & $\begin{array}{c}0.70^{+} \\
(0.31) \\
{[0.01]}\end{array}$ & $\begin{array}{c}1.90^{*} \\
(0.20) \\
{[0.08]}\end{array}$ & $\begin{array}{c}1.95^{*} \\
(0.25) \\
{[0.27]}\end{array}$ & $\begin{array}{c}1.85^{*} \\
(0.18) \\
{[0.01]}\end{array}$ & $\begin{array}{c}1.02^{*} \\
(0.31) \\
{[0.01]}\end{array}$ & $\begin{array}{c}1.06^{*} \\
(0.33) \\
{[0.01]}\end{array}$ & $\begin{array}{c}0.61 \\
(0.48) \\
{[0.01]}\end{array}$ \\
\hline F: & Only thefts involving break-in ${ }^{\mathrm{d}}$ & $\begin{array}{c}1.40^{*} \\
(0.20) \\
{[0.06]}\end{array}$ & $\begin{array}{c}1.24^{*} \\
(0.17) \\
{[0.20]}\end{array}$ & $\begin{array}{c}1.16^{*} \\
(0.13) \\
{[0.08]}\end{array}$ & $\begin{array}{c}0.77^{*} \\
(0.11) \\
{[0.01]}\end{array}$ & $\begin{array}{c}0.75^{*} \\
(0.11) \\
{[0.01]}\end{array}$ & $\begin{array}{c}0.64^{*} \\
(0.09) \\
{[0.01]}\end{array}$ & $\begin{array}{c}1.48^{*} \\
(0.22) \\
{[0.03]}\end{array}$ & $\begin{array}{c}1.28^{*} \\
(0.19) \\
{[0.14]}\end{array}$ & $\begin{array}{c}1.23^{*} \\
(0.11) \\
{[0.01]}\end{array}$ & $\begin{array}{c}0.94^{*} \\
(0.15) \\
{[0.01]}\end{array}$ & $\begin{array}{c}0.96^{*} \\
(0.15) \\
{[0.01]}\end{array}$ & $\begin{array}{c}0.80^{*} \\
(0.19) \\
{[0.01]}\end{array}$ \\
\hline G: & Outcome replaced by log of stolen bicycles ${ }^{\mathrm{e}}$ & $\begin{array}{c}0.02 \\
(0.09) \\
{[0.22]}\end{array}$ & $\begin{array}{r}-0.04 \\
(0.10) \\
{[0.19]}\end{array}$ & $\begin{array}{c}-0.08 \\
(0.07) \\
{[0.02]}\end{array}$ & $\begin{array}{c}-0.24^{+} \\
(0.10) \\
{[0.05]}\end{array}$ & $\begin{array}{r}-0.25^{*} \\
(0.09) \\
{[0.07]}\end{array}$ & $\begin{array}{c}-0.17 \\
(0.11) \\
{[0.04]}\end{array}$ & $\begin{array}{c}0.03 \\
(0.10) \\
{[0.21]}\end{array}$ & $\begin{array}{c}-0.08 \\
(0.13) \\
{[0.44]}\end{array}$ & $\begin{array}{c}-0.08 \\
(0.08) \\
{[0.15]}\end{array}$ & $\begin{array}{c}-0.28^{+} \\
(0.12) \\
{[0.04]}\end{array}$ & $\begin{array}{c}-0.26^{+} \\
(0.10) \\
{[0.07]}\end{array}$ & $\begin{array}{r}-0.19 \\
(0.17) \\
{[0.05]}\end{array}$ \\
\hline $\mathrm{H}:$ & DOLS models with single leads and lags & & & & & & & $\begin{array}{c}1.39^{*} \\
(0.09) \\
{[0.15]}\end{array}$ & $\begin{array}{c}1.48^{*} \\
(0.10) \\
{[0.11]}\end{array}$ & $\begin{array}{c}1.45^{*} \\
(0.07) \\
{[0.02]}\end{array}$ & $\begin{array}{c}1.23^{*} \\
(0.10) \\
{[0.01]}\end{array}$ & $\begin{array}{c}1.23^{*} \\
(0.09) \\
{[0.01]}\end{array}$ & $\begin{array}{c}1.12^{*} \\
(0.11) \\
{[0.01]}\end{array}$ \\
\hline I: & DOLS models with three leads and lags & & & & & & & $\begin{array}{c}1.44^{*} \\
(0.09) \\
{[0.08]}\end{array}$ & $\begin{array}{c}1.52^{*} \\
(0.10) \\
{[0.02]}\end{array}$ & $\begin{array}{c}1.51^{*} \\
(0.07) \\
{[0.01]}\end{array}$ & $\begin{array}{c}0.99^{*} \\
(0.10) \\
{[0.01]}\end{array}$ & $\begin{array}{c}1.00^{*} \\
(0.09) \\
{[0.01]}\end{array}$ & $\begin{array}{c}1.01^{*} \\
(0.11) \\
{[0.01]}\end{array}$ \\
\hline $\mathrm{J}:$ & DOLS models with four leads and lags & & & & & & & $\begin{array}{c}1.50^{*} \\
(0.09) \\
{[0.24]}\end{array}$ & $\begin{array}{c}1.57^{*} \\
(0.10) \\
{[0.04]}\end{array}$ & $\begin{array}{l}1.54^{*} \\
(0.07) \\
{[0.01]}\end{array}$ & $\begin{array}{c}1.04^{*} \\
(0.10) \\
{[0.01]}\end{array}$ & $\begin{array}{c}1.29^{*} \\
(0.09) \\
{[0.01]}\end{array}$ & $\begin{array}{c}1.69^{*} \\
(0.11) \\
{[0.01]}\end{array}$ \\
\hline $\mathrm{K}$ : & Log copper replaced by price index ${ }^{\mathrm{f}}$ & $\begin{array}{c}1.59^{*} \\
(0.16) \\
{[0.03]}\end{array}$ & $\begin{array}{c}1.57^{*} \\
(0.14) \\
{[0.06]}\end{array}$ & $\begin{array}{c}1.50^{*} \\
(0.12) \\
{[0.10]}\end{array}$ & $\begin{array}{l}1.18^{*} \\
(0.11) \\
{[0.01]}\end{array}$ & $\begin{array}{c}1.19^{*} \\
(0.11) \\
{[0.01]}\end{array}$ & $\begin{array}{c}1.06^{*} \\
(0.14) \\
{[0.01]}\end{array}$ & $\begin{array}{l}1.67^{*} \\
(0.16) \\
{[0.04]}\end{array}$ & $\begin{array}{c}1.63^{*} \\
(0.14) \\
{[0.04]}\end{array}$ & $\begin{array}{c}1.58^{*} \\
(0.11) \\
{[0.01]}\end{array}$ & $\begin{array}{c}1.17^{*} \\
(0.16) \\
{[0.01]}\end{array}$ & $\begin{array}{c}1.18^{*} \\
(0.17) \\
{[0.01]}\end{array}$ & $\begin{array}{c}1.15^{*} \\
(0.25) \\
{[0.01]}\end{array}$ \\
\hline L: & Outcome replaced by $\log$ of all metal-related thefts $\mathrm{g}$ & $\begin{array}{c}1.29^{*} \\
(0.14) \\
{[0.01]}\end{array}$ & $\begin{array}{c}1.24^{*} \\
(0.12) \\
{[0.04]}\end{array}$ & $\begin{array}{c}1.18^{*} \\
(0.10) \\
{[0.04]}\end{array}$ & $\begin{array}{c}0.94^{*} \\
(0.10) \\
{[0.01]}\end{array}$ & $\begin{array}{c}0.94^{*} \\
(0.09) \\
{[0.01]}\end{array}$ & $\begin{array}{c}0.82^{*} \\
(0.12) \\
{[0.01]}\end{array}$ & $\begin{array}{c}1.36^{*} \\
(0.14) \\
{[0.02]}\end{array}$ & $\begin{array}{c}1.29^{*} \\
(0.11) \\
{[0.06]}\end{array}$ & $\begin{array}{c}1.25^{*} \\
(0.09) \\
{[0.01]}\end{array}$ & $\begin{array}{c}0.91^{*} \\
(0.13) \\
{[0.01]}\end{array}$ & $\begin{array}{c}0.93^{*} \\
(0.15) \\
{[0.01]}\end{array}$ & $\begin{array}{c}0.84^{*} \\
(0.19) \\
{[0.01]}\end{array}$ \\
\hline & servations & 120 & 120 & 119 & 119 & 119 & 119 & 115 & 115 & 114 & 114 & 114 & 114 \\
\hline
\end{tabular}

Notes: Table reports alternative estimates of models (1) through (12) from Table 4. Only the estimates of the effect of copper price on thefts are reported; detailed results are available upon request. Heteroskedasticity and autocorrelation robust standard errors (Newey and West 1987) are in parentheses: ${ }^{+} p<0.05,{ }^{*} p<0.01$. Square brackets report $p$-values of Augmented Dickey-Fuller tests for each model (values below 0.01 are reported as 0.01 ) ${ }^{a}$ The outcome is the logarithm of the number of metal thefts with total damage below $5,000 \mathrm{CZK}$. ${ }^{\mathrm{b}}$ The outcome is the logarithm of the number of metal thefts with a value of stolen material below $5,000 \mathrm{CZK}$. ${ }^{\mathrm{c}}$ The outcome is the logarithm of the number of metal thefts with a value of stolen material equal to zero. ${ }^{d}$ The outcome is the logarithm of the number of metal thefts which involved break-in and thus $5,000 \mathrm{CZK}$. ${ }^{\circ}$ The outcome is the logarithm of the number of metal thefts with a value of stolen material equal to zero. ${ }^{d}$ The outcome is the logarithm of the number of metal thefts which involved break-in and thus
qualified as crimes regardless of the damage. ${ }^{\text {e }}$ The outcome is the logarithm of the number of bicycle thefts classified as crime. Specifications are identical to those in Table 4 , except bicycle thefts are dropped from the explanatory variables. ${ }^{\mathrm{f}} \mathrm{Log}$ of copper price is replaced by the logarithm of price index consisting of aluminum and copper with weights fixed at $1 / 3$ and $2 / 3$, respectively. The choice of weights was motivated by patterns in Table 1. ${ }^{\mathrm{g}}$ The outcome is the logarithm of the number of all thefts involving nonferrous metals, that is all thefts where one of the objects was metal. 
To further probe this issue, we exploit the fact that the 5,000 CZK threshold is a sufficient but not necessary condition for an offense to qualify as a crime. We thus reestimate the models from Table 4 with the outcome variable computed as the monthly number of metal thefts with damage below 5,000 CZK. For these thefts the damage threshold had no impact. If the mechanical relationship between copper price and damage is important, this measure should clearly undervalue the change in thefts due to the change in prices, as it mechanically excludes thefts that exceed the 5,000 CZK margin. If that were the case, these estimates of price elasticity could be interpreted as conservative. Consistent with our predictions, the estimates of the effect of copper prices on metal theft with damage below the threshold in block $\mathrm{C}$ are mostly somewhat smaller than our baseline estimates in Table 4. Yet, in specification (6) and the DOLS specifications (10), (11), and (12), the estimated elasticity is higher than in the corresponding baseline models, which would be consistent with the hypothesis that small offenses react disproportionately to shocks in prices. However, the patterns and magnitudes of both sets of estimates are comparable and the differences in coefficients are not statistically significant. Similar results are found when the outcome is defined as the number of metal thefts with a value of stolen goods less than 5,000 CZK and zero CZK, as reported in blocks D and E, respectively.

In block F we reestimate our baseline models with the outcome defined as the log of the number of thefts involving break-in (about one third of all metal thefts). These offenses qualify as crimes regardless the size of the resulting damage so that the 5,000 CZK threshold is irrelevant. The estimates of the elasticity of break-in thefts are slightly smaller than the baseline models, but these differences are not statistically significant. To summarize, these results are inconsistent with the interpretation that the relationship between copper prices and metal thefts in our data is an artifact of the mechanical relationship between copper price and the number of metal thefts that qualify as crimes.

\subsection{Substitution Across Criminal Activities}

Understanding, whether the price-theft relationship in our data represents a net variation in criminal activity (i.e. substitution between legitimate and ilegitimate activity), or rather 
shifts in the allocation of effort across alternative crimes (substitution between ilegitimate activities), is relevant from the substantive as well as policy perspectives. In order to control for general crime trends and potential substitution across criminal opportunities, we include property crime and bicycle thefts as explanatory variables in our regressions. However, one might argue, that these variables also contain a noise that is unrelated to substitution effects, if any. ${ }^{21}$ As a result, potential substitution effects may not properly controlled for.

Other researchers have investigated substitution between criminal activities in response to crime-specific shocks in deterrence, mainly stemming from changes in arrest rates (Cameron 1987; Koskela and Viren 1997; Levitt 1998). Their results however need to be interpreted cautiously, because thieves may not directly observe arrest rates and the resulting shocks in the relative value of criminal opportunities (Levitt 1998). Our situation is different, since shocks in the market value of stolen material affect the relative value of metal theft directly and observably. Thus, our setting is better suited for identification of substitution between criminal activities.

A direct way to test the substitution hypothesis is simply to regress the substitute criminal activities on copper prices. Since we only possess data on bicycle thefts, which is plausibly a substitute to metal theft, we reestimate regression (1) with the log of bicycle thefts as the outcome variable. Note that bicycle thefts and metal thefts are relatively comparable crimes in terms of frequency and magnitude of events (see Table 3); bicycle thefts are almost twice as frequent, but the average damage in our data is $13,600 \mathrm{CZK}$, or about 38 percent of the average metal theft damage. The results are reported in block $\mathrm{G}$ of Table 6 . The estimates are mostly negative, which is consistent with the substitution hypothesis, and in specifications that control for business cycle (unemployment, wages, and S\&P 500), the estimated cross-elasticity is about 0.25 . However in most cases, the point estimates are smaller, not statistically significant, and often close to zero. When the largest estimates from block $\mathrm{G}$ are taken at their face value, substitution between bicycle

\footnotetext{
${ }^{21}$ See also the discussion in footnote 15 .
} 
theft and metal theft may explain about 20-25 percent of the price elasticity of copper thefts in our data.

\subsection{Robustness Checks}

The remainder of Table 6 offers additional specification checks. Blocks H, I, and J report the results of DOLS models from Table 4 with alternative numbers of leads and lags (one, three, and four) of differenced explanatory variables. The results are similar to the baseline DOLS estimates and the differences in coefficients are not statistically significant. To check the sensitivity of our results to our choice of price index, we then replace the log copper price with the log of composite prices, consisting of the LME prices of aluminum and copper with weights of $1 / 3$ and $2 / 3$, respectively. This choice was motivated by the results in Table 1, which suggest that these two metals constitute the bulk of metal thefts. The estimates of elasticity, reported in block K, are about 5 to $30 \log$ points higher across the 12 specifications, but the differences are largely not statistically significant. Lastly, in block $\mathrm{L}$ we replace the outcome variable, the log of the number of primary metal thefts, by the number of all thefts involving metals. That is, we include thefts whose primary object was something other than metal. The estimates of price elasticity for such metal thefts with respect to copper price are about $20 \log$ points smaller, and five out of 12 estimates are smaller than unity, but the distance is not statistically significant.

\section{Conclusion}

This paper tested an economic model of criminal behavior using data on metal thefts in the Czech Republic over a ten-year period from 2003 until 2012. During this period nonferrous metal prices varied widely. We argue that this variation in metal prices constitutes a natural experiment involving metal thieves. This is because metal prices are set on the world market, in which stolen metal in the Czech Republic is unlikely to play an important role. While one may still contest that there is an endogenous element in world copper prices with respect to the activity of metal thieves, if this were the case, the 
observed relationship between metal prices and thefts in the data would be weaker then the true causal effect of price change on thefts, making our results conservative. Another criticism of our results might point to endogeneity of enforcement (see e.g. Cook 1986; Cook and MacDonald 2011; Tsebelis 1989). When thefts surge, individuals and the police have greater incentives to invest into preventing thefts and pursuing offenders. Apart from the clearance rate included in our regressions, we do not have data on numbers of police allocated to solving metal thefts, neither do we possess data on private spending on crime prevention. We may however note that endogenous enforcement would again work against our hypothesis, making our results conservative. Our results are thus consistent with the economic model of crime, wherein criminal behavior is modeled as a rational agent's decision driven by the cost-benefit ratio of undertaking criminal activities. We must conclude that opportunity makes the thief. 


\section{References}

Aruga, Kentaka and Shunsuke Managi. 2011. "Price Linkages in the Copper Futures, Primary, and Scrap Markets.” Resources, Conservation and Recycling 56:43-47.

Ayres, Ian and John J. Donohue, III. 2003. "Shooting Down the More Guns, Less Crime Hypothesis." Stanford Law Review 55:1193-1312.

Beccaria, Cesare. 1995 [1764]. On crimes and punishments and other writings. Cambridge and New York: Cambridge University Press.

Becker, Gary S. 1968. “Crime and Punishment: An Economic Approach.” Journal of Political Economy 76:169-217.

Bennett, Luke. 2008. "Assets under attack: metal theft, the built environment and the dark side of the global recycling market." Environmental Law and Management 20:176-183.

Bennett, Oliver. 2012a. “Scrap Metal Dealers Bill.” Research Paper no. 12/39, House of Commons Library, London.

. 2012b. "Scrap Metal Dealers Bill: Committee Stage Report.” Research paper, House of Commons Library, London.

Bentham, Jeremy. 1823. An Introduction to the Principles of Morals and Legislation, vol. II. London: Printed for W. Pickering.

— 2008 [1830]. The rationale of punishment. Amherst, NY: Prometheus.

Cameron, Samuel. 1987. "Substitution Between Offence Categories in the Supply of Property Crime: Some New Evidence.” International Journal of Social Economics $14: 48-60$.

Chisholm, John and Chongwoo Choe. 2005. "Income variables and the measures of gains from crime." Oxford Economic Papers 57:112-119.

Cook, Philip J. 1986. "The Demand and Supply of Criminal Opportunities.” Crime and Justice 7:1-27. 
— 2010. "Property crime-yes; violence_no." Criminology \& Public Policy 9:693-697.

Cook, Philip J. and John MacDonald. 2011. "Public Safety through Private Action: an Economic Assessment of BIDS.” Economic Journal 121:445-462.

Cook, Philip J. and Gary A. Zarkin. 1985. "Crime and the Business Cycle.” Journal of Legal Studies 14:115-128.

Davidson, Russell and James G. MacKinnon. 2003. Econometric Theory and Methods. Oxford University Press, USA.

Detotto, Claudio and Manuela Pulina. 2013. "Assessing Substitution and Complementary Effects Amongst Crime Typologies." European Journal on Criminal Policy and Research 19:309-332.

Di Tella, Rafael and Ernesto Schargrodsky. 2004. "Do Police Reduce Crime? Estimates Using the Allocation of Police Forces After a Terrorist Attack." American Economic Review 94:115-133.

Draca, Mirko, Theodore Koutmeridis, and Stephen Machin. 2015. "The Changing Returns to Crime: Do Criminals Respond to Prices?" Unpublished manuscript, Centre for Economic Performance, London School of Economics.

d'Este, Rocco. 2014. “The Effect of Stolen Goods Markets on Crime: Pawnshops, Property Thefts and the Gold Rush of the 2000s." Unpublished manuscript, University of Warwick.

Ehrlich, Isaac. 1973. "Participation in Illegitimate Activities: A Theoretical and Empirical Investigation." Journal of Political Economy 81:521-65.

1996. "Crime, Punishment, and the Market for Offenses." Journal of Economic Perspectives 10:43-67.

Engle, Robert F. and C. W. J. Granger. 1987. "Co-Integration and Error Correction: Representation, Estimation, and Testing." Econometrica 55:251. 
Jones, M. C., J. S. Marron, and S. J. Sheather. 1996. “A Brief Survey of Bandwidth Selection for Density Estimation.” Journal of the American Statistical Association 91:401-407.

Klick, Jonathan and Alexander Tabarrok. 2005. "Using Terror Alert Levels to Estimate the Effect of Police on Crime." Journal of Law and Economics 48:267-279.

Kooi, Brandon R. 2010. “Theft of Scrap Metal.” Problem-oriented Guides for Police Series no. 58, U.S. Department of Justice, Washington, DC.

Koskela, Erkki and Matti Viren. 1997. "An occupational choice model of crime switching." Applied Economics 29:655-660.

Labys, W. C., H. J. B. Rees, and C. M. Elliott. 1971. "Copper Price Behaviour and the London Metal Exchange." Applied Economics 3:99-113.

Levitt, Steven D. 1997. "Using Electoral Cycles in Police Hiring to Estimate the Effect of Police on Crime." American Economic Review 87:270-290.

— 1998. "Why Do Increased Arrest Rates Appear to Reduce Crime: Deterrence, Incapacitation, or Measurement Error?” Economic Inquiry 36:353-372.

_ 2002. "Using Electoral Cycles in Police Hiring to Estimate the Effects of Police on Crime: Reply.” American Economic Review 92:1244-1250.

Lipscombe, Sally and Oliver Bennett. 2012. "Metal theft." Standard Note no. SN/SHA/6150, House of Commons Library, London.

Lott, Jr., John R. and David B. Mustard. 1997. “Crime, Deterrence, and Right-to-Carry Concealed Handguns." Journal of Legal Studies 26:1-68.

McGill, Robert, John W. Tukey, and Wayne A. Larsen. 1978. "Variations of Box Plots." American Statistician 32:12-16.

Montag, Josef. 2014. "A Radical Change in Traffic Law: Effects on Fatalities in the Czech Republic.” Journal of Public Health 36:539-545. 
Murray, Michael P. 1994. “A Drunk and Her Dog: An Illustration of Cointegration and Error Correction." American Statistician 48:37-39.

Newey, Whitney K. and Kenneth D. West. 1987. “A Simple, Positive Semi-Definite, Heteroskedasticity and Autocorrelation Consistent Covariance Matrix." Econometrica $55: 703-708$.

Posick, Chad, Michael Rocque, Kevin Whiteacre, and David Mazeika. 2012. "Examining Metal Theft in Context: An Opportunity Theory Approach.” Justice Research and Policy 14:79-102.

Posner, Richard A. 1985. "An Economic Theory of the Criminal Law." Columbia Law Review 85:1193-1231.

Saikkonen, Pentti. 1991. "Asymptotically Efficient Estimation of Cointegration Regressions.” Econometric Theory 7:1-21.

Sheather, S. J. and M. C. Jones. 1991. "A Reliable Data-Based Bandwidth Selection Method for Kernel Density Estimation.” Journal of the Royal Statistical Society. Series B (Methodological) 53:683-690.

Sidebottom, Aiden, Matt Ashby, and Shane D. Johnson. 2014. "Copper Cable Theft: Revisiting the Price-Theft Hypothesis." Journal of Research in Crime and Delinquency 51:684-700.

Sidebottom, Aiden, Jyoti Belur, Kate Bowers, Lisa Tompson, and Shane D. Johnson. 2011. "Theft in Price-Volatile Markets: On the Relationship between Copper Price and Copper Theft." Journal of Research in Crime and Delinquency 48:396-418.

Stock, James H. and Mark W. Watson. 1993. "A Simple Estimator of Cointegrating Vectors in Higher Order Integrated Systems.” Econometrica 61:783-820.

Tsebelis, George. 1989. “The Abuse of Probability in Political Analysis: The Robinson Crusoe Fallacy." American Political Science Review 83:77-91. 
Watkins, Clinton and Michael McAleer. 2004. "Econometric Modelling of Non-ferrous Metal Prices." Journal of Economic Surveys 18:651-701. 


\section{Appendix}

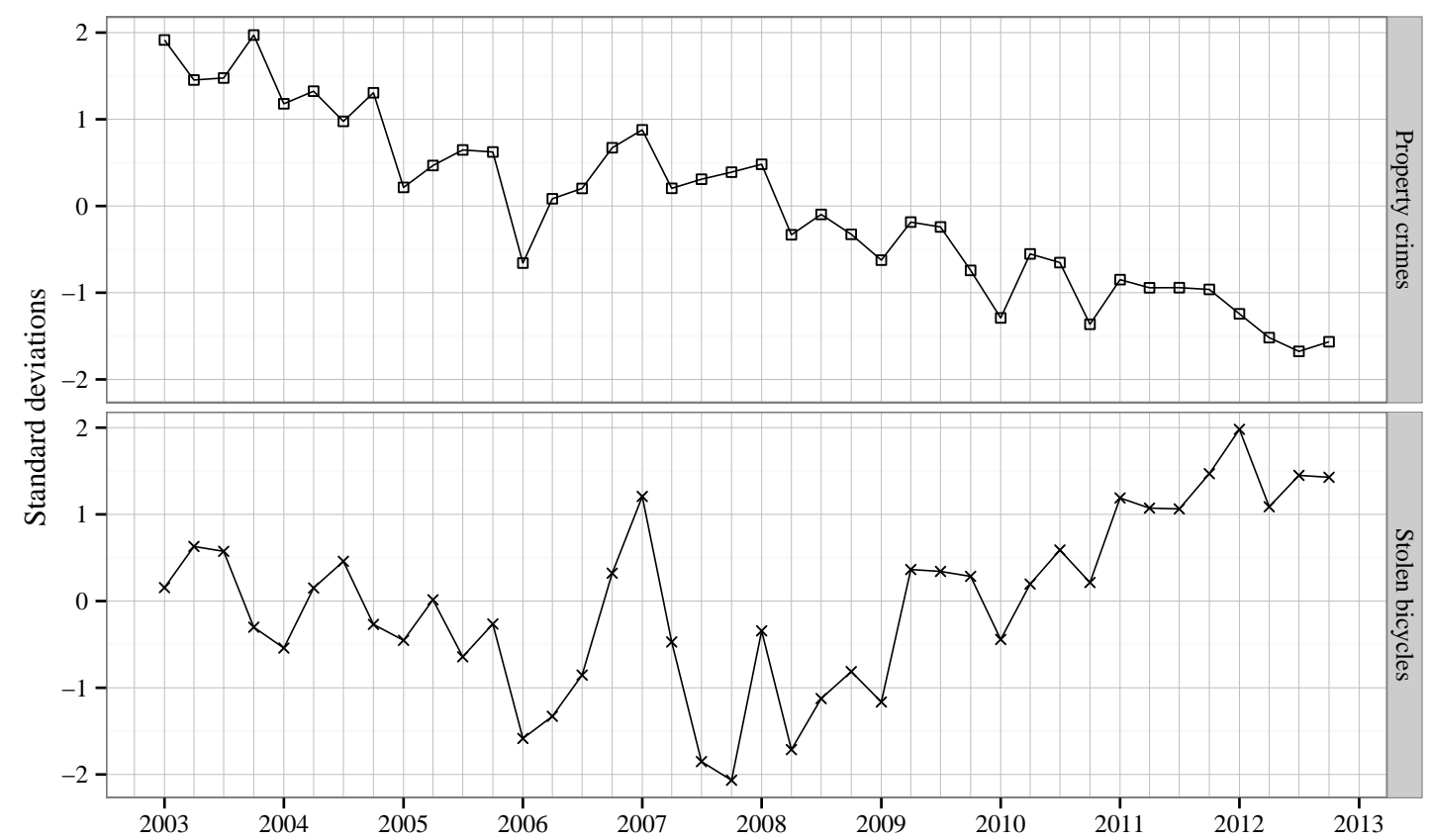

Figure A1: Property crime and bicycle theft (that qualify as crime) reported to the Czech Police. Data are deseasoned, demeaned, and divided by respective standard deviations. 

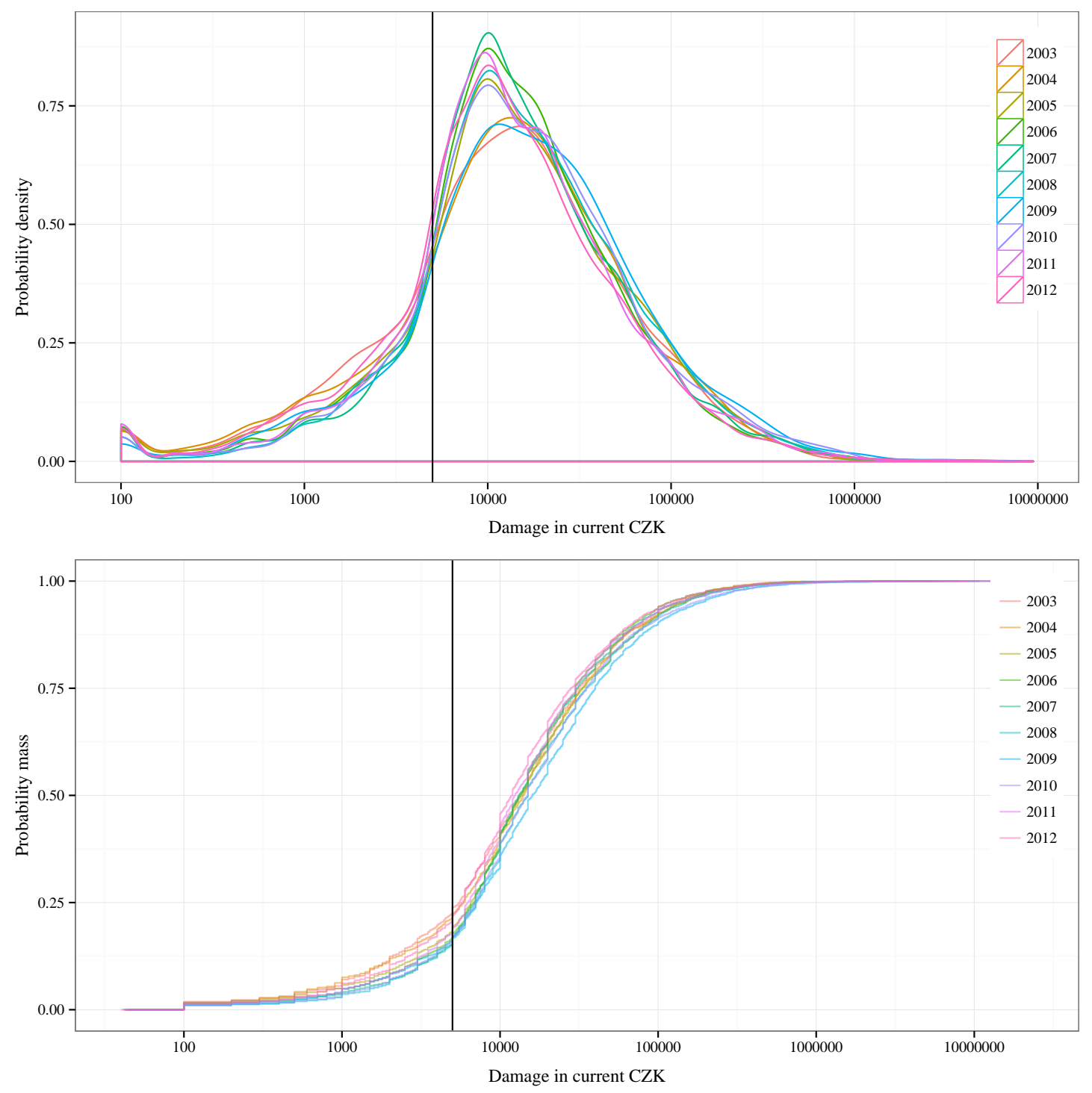

Figure A2: Plots of distributions of damage from individual metal thefts (logarithmic scales with damage below 10 CZK coded as 10 to save space). Bandwidth selected according to the Sheather and Jones's (1991) algorithm (Jones, Marron, and Sheather 1996). 


\begin{abstract}
Abstrakt
Lidé kradou měd’ a další drahé kovy s cílem zpeněžení ve výkupnách. Současně, výkupní ceny jsou ustavovány na světovém trhu. My argumentujeme, že šoky v cenovách kovů tak generují kvasi-experimentální variaci v hodnotě lupu. To nám umožňuje odhadnout behaviorální parametry nabídky trestných činů a testovat ekonomickou teorii zločinu. Naše odhady ukazují, že dlouhodobá elasticita nabídky krádeží kovů, s ohledem na výkupní hodnotu ukradeného materiálu, je mezi jednou a 1,5. Navíc, systém se velmi rychle vrací do ekvilibria - mezi 30 a 60 procenty disekvilibria je napraveno během následujícího měsíce a odhady měsíční cenové elasticity jsou kolem jedné.
\end{abstract}




\section{Working Paper Series}

ISSN 1211-3298

Registration No. (Ministry of Culture): E 19443

Individual researchers, as well as the on-line and printed versions of the CERGE-EI Working Papers (including their dissemination) were supported from institutional support RVO 67985998 from Economics Institute of the ASCR, v. v. i.

Specific research support and/or other grants the researchers/publications benefited from are acknowledged at the beginning of the Paper.

(c) Tomáš Brabenec and Josef Montag, 2016

All rights reserved. No part of this publication may be reproduced, stored in a retrieval system or transmitted in any form or by any means, electronic, mechanical or photocopying, recording, or otherwise without the prior permission of the publisher.

Published by

Charles University in Prague, Center for Economic Research and Graduate Education (CERGE) and

Economics Institute of the CAS, v. v. i. (EI)

CERGE-El, Politických vězňů 7, 11121 Prague 1, tel.: +420 224005 153, Czech Republic.

Printed by CERGE-EI, Prague

Subscription: CERGE-EI homepage: http://www.cerge-ei.cz

Phone: + 420224005153

Email: office@cerge-ei.cz

Web: http://www.cerge-ei.cz

Editor: Jan Zápal

The paper is available online at http://www.cerge-ei.cz/publications/working_papers/.

ISBN 978-80-7343-365-9 (Univerzita Karlova v Praze, Centrum pro ekonomický výzkum a doktorské studium)

ISBN 978-80-7344-369-6 (Národohospodářský ústav AV ČR, v. v. i.) 
CERGE-EI

P.O.BOX 882

Politických vězňů 7

11121 Praha 1

Czech Republic http://www.cerge-ei.cz 